\title{
Whiteness and the Blackening of Italy: La guerra cafona, Extracommunitari and Provisional Street Justice
}

\author{
Joseph Pugliese, Macquarie University
}

\section{Introduction}

In his La guerra 'cafona' (The 'Cafona' War), Salvatore Scarpino presents a detailed account of the decade long war staged by southern Italian insurgents in the wake of the unification of the Italian peninsula in 1861. The term cafone originated in the South and it simply referred to poor rural folk; it originally had no derogatory connotations. After Italian unification, however, cafone began to be deployed by northern Italians as an insulting term to describe Southerners; its range of significations included 'primitive,' 'barbaric,' 'uncivilised,' 'vulgar' and 'backward.' In his book, Scarpino maps the complex and contradictory modes of resistance exercised by southern subalterns, including landless peasants and outlaws, against the North's violent war of colonial annexation of the South. Categorised by the North as the Cafona War, that is, as the war of the civilised against the barbaric, the North proceeded to deploy both colonial and paracolonial methods in order to bring the South under its control and thus secure the political, economic and cultural transformation of the South into a 'Piedmontese province’ (Scarpino 2005: 29). ${ }^{1}$ As Luciano Salera explains, 'This was the beginning of the use of 'brigandage,' the term by which the armed Northerners attempted to defame the [South's] rebellious peasants' (2006: 31). Scarpino and Salera, in their respective critical accounts of southern brigandage, systematically expose how the North's deployment of the term worked to script southern anti-unification insurgents in terms of bands of savage and petty criminals, thereby depoliticising their struggle against the

\footnotetext{
${ }^{1}$ All translations from Neapolitan, Sicilian and Italian are by the author. 
violent process of unification. This politico-linguistic move 'was essential,' Salera writes, "in order to whitewash minds, extirpating this "historical memory" so as, finally, to make Southerners ashamed of their own origins! And this was done scientifically!' (2006: 31). In his invocation of science, Salera draws attention to the establishment, soon after unification, of the school of Meridionalisti (Southernists). Constituted by criminal anthropologists, eugenicists, phrenologists, craniologists and ethno-linguists, the school's members laboured assiduously to ground their theories of southern congenital inferiority in forms of scientifico-biological racism (Teti 1993; Schneider 1998; Dickie 1999; Pugliese 2002a, 2002b, 2007a; Moe 2002).

In the course of this essay, I want briefly to revisit the historical moment of Italian unification, drawing attention to its violent colonial dimensions and the years of southern brigandage that inscribed it, and tracing the survival of this insurrectionary and anti-nationalist movement in contemporary Italy. By focusing on the exuberant manner in which a statue of the Italian national poet, Dante, has been graffitied by southern youth in a square in Naples, I want to resignify the historical tradition of southern brigandage — by returning the term back to its insurgent political roots—and thus to establish lines of connection between seemingly disparate politico-cultural practices and genealogies. Specifically, I examine southern hip hop culture (specifically graffiti and rap) in relation to the history of southern anti-unification and counter-nationalist movements. As Francesco Mario Agnoli writes, critically coming to terms with the history of southern brigandage in post-unification Italy 'is indispensable to understanding the relations between Southerners and the State and the problems that followed, including the financing of public administration, immigration, and even the emergence of the Northern League' (2005: 23).

This analysis of southern hip hop culture interrogates whiteness as constitutive of hegemonic Italian identity, politics and culture. I conclude by bringing into contemporary focus the northern history of anti-southern discrimination and exploitation, drawing attention to the plight of recent immigrants from the Global South who form the underbelly of contemporary Italy's economic prosperity. Focusing on contemporary debates on extracomunitari in Italy, I attempt to delineate a tactical blackening of Italy in the face of a virulent and violent caucacentrism. 


\section{Southern Brigandage against a Unified Italian Nation-State}

Up until, and immediately after, the moment of unification, northern Italians viewed the South as a type of terra incognita. Knowledge of the South was largely gathered from the accounts and travelogues of European travellers who ventured into the nether regions of the peninsula and returned to tell their tales. Immediately after the moment of unification, a collection of northern Italian politicians, bureaucrats and academics descended into the South in order to begin the process of integrating the region into the larger body of the Italian nation-state. This descent into the South was viewed as a process of discovery and colonisation (Gramsci 1975, 2005). A contemporary account published in a newspaper of Lombardy (one of the main loci of the unification movement) articulates the labour of discovery that lay ahead for a post-unified Italy: 'The first, the most important work we need to accomplish as Italians is, and must be, the discovery of Italy. For most of us - and of course it is not our fault-Italy is a bit like Africa for geographers ... we find ourselves in terre ignote .... Therefore we say that we must rise to the task of discovering Italy' (quoted in Petraccone 2000: 56).

Africa, in fact, became the governing metaphor through which Northerners began to make sense of the South. Consequently, the northern dominated nationalist government utilised a colonial model that would establish 'special careers with certain advantages like the House for Indian Affairs in England' (Petraccone 2000: 101). The deployment of the loaded signifier 'Africa,' as the lens through which the South was rendered intelligible for Northerners, marks how the question of Italy was, from the very moment of unification, already racialised by a geopolitical fault line that split the peninsula and its islands along a black/white axis. From the beginning, then, the so-called questione meridionale (Southern question) encoded a set of racialised presuppositions in which the whiteness of the North operated as an a priori, in contradistinction to the problematic racialised status of the South, with its dubious African and Oriental histories and cultures.

In his painstaking documentation of the atrocities perpetrated by the northern forces in the execution of the Cafona War, Scarpino writes:

The massacres, in fact, were not absent. It is useless to list them one by one, because they were all equally atrocious and stupid. The force of the repression was proportional to the ignorance and insensibility of the political authorities and, above all, the military. There was, in many of the 
officials' views of the South, an exasperated paracolonial attitude based on the observation that in the South the real war began once the official war [of unification] had actually ceased. $(2005,41)$

In the process of asserting its moral superiority over the South and in its attempt to contain, neutralise and recode the political dimensions of the insurgency, the North declared the South a 'zone of brigandage' (Scarpino 2005: 150). It thereby effectively criminalised the insurgents, reducing them to lawless bands of petty criminals. By declaring the South a 'zone of brigandage,' the North argued that the 'southern territories were infested with brigands, so much so as to declare the phenomenon as “endemic,” when, in fact, it became manifest only after [northern] annexation, and then not as a phenomenon of mass criminality, as Northerners framed it, but as a political and social rebellion' (Salera 2006: 78).

The subsequent passing of the Legge pica (Pica Law), on August 15, 1863, in order to repress and liquidate brigandage, functioned to legalise the use of state-sponsored violence by both military and paramilitary forces (Izzo 2005: 146). The anti-brigandage Pica Law, writes Scarpino, 'clearly indicates that the new State was exclusively preoccupied with repression and with extraordinary legislation, staging a profoundly illiberal act in the name of the liberty it was purportedly bringing to the South' (2005: 157). As Aldo De Jaco makes clear in his documentary history of southern brigandage, under the aegis of the Pica Law northern forces indiscriminately massacred with absolute impunity children, women and men, pillaging and setting fire to entire villages, decapitating their captives, and exhibiting their heads on stakes around the captured towns and villages (De Jaco 2005; Scarpino 2005). Roberto Martucci, in his detailed account of what he terms a 'civil war,' draws attention to the scorched earth policies unleashed by Northern forces on 'uncooperative' villages and towns in the South (2007: 323, 305, 419). The term 'civil war' has not, in fact, been anachronistically coined and imposed by contemporary historians of the South in their writings on the Cafona War. On the contrary, the term was first deployed by politicians, journalists and other observers attempting to describe the scale of the violence unleashed by the northern annexation of the South (Di Fiore 2008: 219).

In his extensive quoting of contemporany documentary sources, Martucci draws attention to the indiscriminate killing of women, children and the elderly, the rape of women, and the incineration of entire families trapped in their houses as they were set 
alight by northern forces (see also Di Fiore 2008: 237-59). One eyewitness describes the massacre and incineration that took place in the town of Casalduni as inscribed by a 'horizon of extermination that knew no limits' (quoted in Martucci 2007: 294). Martucci utilises the analogy of the American Apache wars to describe the violent asymmetry of power that was played out in the Cafona War (2007: 302-3). He underscores, furthermore, the manner in which the exterminatory violence visited upon the inhabitants of the South was viewed, in contemporary accounts, as coextensive with other colonial precedents:

\footnotetext{
Pietro Calà d'Ulloa, counsellor of the supreme court of Naples ... tried to solicit European public opinion by glossing a long catalogue of northern abuses in terms of past and contemporary colonial practices: 'did not the English do the same things in India, the French in Algeria, did not the Spanish act with the same violent dexterity against the barbaric natives in Mexico and Peru?' This invocation of past colonial practices was not in fact a novelty. Already in his parliamentary speech of 20 September 1861, the member of parliament Marzio Proto, duke of Maddaloni, raised a vibrant and unexpected protest against the policy of extermination, arguing that the 'government of Piedmont wants to treat the southern provinces as Cortes or Pizzaro did in Peru and in Mexico ... as the English did in Bengal.' But the British model of colonial relations was not only invoked in order to stigmatise the arbitrary extension of force over the southern provinces of Italy. Precisely in Turin, in 1862, an anonymous commentator had suggested that the best way to deal with the rebellious Southerners was offered by the example of the British colonial troops who, in the great insurrection of 1856, indiscriminately shot down the indigenous Sepoys in their thousands. (2007: 294-95)
}

Luciano Salera, in turn, documents the " "holding” and "concentration” camps that interned the dissolved Regio Esercito Napolitano [the Neapolitan kingdom's official army], the "lager" Sabaudi of Genoa and Allessandria, and of Fenestrelle and San Maurizio; these all bring to conclusion the trilogy of massacres perpetrated by the Piedmontese' (2006: 32; see also Di Fiore 2008: 176-78; Izzio 1999). In this violent period, the process of Italian unification emerges as 'a colonial campaign masquerading under pseudo-ideals of liberty, unity and so on ... that culminated in the perverse strategies of [northern] contempt, humiliation, and the moral and material lynching of the vanquished side of this war' (Salera 2006: 31). The Pica Law formally 'legalised the state of exception' that saw the suspension of Southerners' civil and legal rights, and the execution of any Southerner found to have 'insulted’ the Italian flag (Martucci 2007: 337, 324). In attempting to calculate the number of southern deaths - estimated to be up to 70,000 - that resulted from this civil war, Martucci draws attention to Italian, and, I would add, Anglophone, historiography's failure to contest what Di Fiore calls ‘la sacrilità del Risorgimento’ (2008: 14), thereby reproducing a resounding silence on this matter through a cultural politics of discursive self-censorship and minoritisation: 
when historians of proven intellectual honesty and rigour, such as Franco Molfese, relegate the number of [Southern] dead to appendices or footnotes dispatched to the bottom of a huge tome, this choice is interpreted as an indice of great scholarly prudence, when in fact it must be seen as an evasive tactic deployed so as not be accused of the embarrassing accusation of lesa patria ('lesser motherland'). So, if the indubitable honesty of Molfese does not push auto-censorship to the edges of conscious omission, then only the diligent patience of a reader habituated to the tedious practice of scrutinising microscopic notes at the end of a book will fend off the possibility of dispatching these facts to the frontiers of oblivion. (Martucci 2007: 312)

Given these discursive historiographical and editorial tactics-deployed to avoid the charge of lesa patria and played out in an even more pronounced manner in the glaring censorship of these massacres in the numerous Italian museums dedicated to romantic and mythologised accounts of the Risorgimento-Sandro Mezzadra argues that contemporary Italy has witnessed a resurgent 'new nationalism' in which the sense of ‘national belonging' has been promoted as a ‘fundamental public value’ (2007: 13). As Mezzadra underscores, this 'new nationalism' must be seen, once it is positioned with the matrix of transnational market forces and globalisation, as simultaneously underpinned by racist forces of exclusion, segregation and boundary marking-issues that I discuss in more detail below.

In the closing pages of The 'Cafona' War, Scarpino emphasises that the dead of that war 'still weigh upon us,' and that the colonial violence inflicted upon the South has generated a lingering sense of 'interior estrangement' that has positioned and marked Southerners as in Italy, but not of Italy (2005: 161). 'From that tragic decade of the Mala Unità [Pathological Unity],' concludes Scarpino, 'our contemporary times have been inflected by misunderstandings and poisons from which we are still attempting to liberate ourselves' (2005: 163). The 'poison' to which Scarpino refers includes the continuing internal racism that persists in the political, economic and cultural othering of the South by the North. 'As if the conquest, the economic exploitation [of the South] and the imposition of a foreign cultural model were not enough,' writes Gabriele Marzocco, 'we [Southerners] have had to put up with the contempt, the racism...and the allegations that we are the "assisted," indolent bludgers' (quoted in Salera 2006: 24).

Reading Scarpino's book as a Southerner travelling through the South, I was struck by the powerful ways in which his historical mapping of southern insurgency against the violence of enforced unification on exclusively northern terms, when applied to the contemporary geopolitical context of the South, effectively shed light on an ongoing 
history of 'interior estrangement' on the part of Southerners in relation to the contemporary Italian nation-state. Soon after the unification of Italy, the racialised 'questione meridionale' (Southern question) was quickly formulated by the North in order to account for the 'backward' and 'uncivilised' status of the South, thus serving to justify violent forms of colonial interventions. As Marzocco argues, the questione meridionale was 'nothing other than an excuse for the subordination, cultural, in the first instance, and then economic and political, of the South by the North; in the course of the twentieth century, nothing much changed; in fact, at the beginning of the twentyfirst century, the divide between North and South continues to become ever more marked’ (2006: 24; see also Galasso 2005).

In his critical reframing of the unification of Italy in terms of a bloody and internal colonial war, Marzocco quotes the historian Petrangelo Buttafuoco, who argues:

\footnotetext{
The conquest of the South is the bloodiest chapter of [internal] Italian history and simultaneously the most ignored .... In this unpublished and terrible history, constituted by atrocities and bloodshed, the South is nothing more than a forgotten victim, an inert mummy in the closet of others' fortunes. Behind every fortune there is always a crime; behind the triumph of Italian ideology, there is only the conquest of the South (2006: 25)
}

Note my qualification with the adjective 'internal' of Buttafuoco's claim that the conquest of the South is 'the bloodiest chapter of Italian history.' Italy's external colonial wars of imperial expansion and conquest - that saw the occupation of Somalia (1891), Abyssinia (1887-1941), Libya (1911-1932) and Ethiopia (1935-36)—unleashed forces of violence that resulted in hundreds of thousands of North African deaths (Del Boca 2002, 2005, 2007). Following Angelo Del Boca’s landmark decolonising work, I have argued elsewhere that this Italian colonial history has only recently begun to be critically analysed; it still has not been acknowledged in any profound way in the Italian nation’s historical or cultural corpus (Pugliese 2007b; Ben-Ghiat and Fuller 2005; Andall and Duncan 2005).

In what follows, I read the graffitying of a monument in the southern city of Naples to Italy's national poet, Dante Alighieri (a monument dedicated in the late nineteenth century in order officially to mark and celebrate Italian unification), in relation to the historical burdens of insurrectionist brigandage that Scarpino maps in his The 'Cafona' War. In resignifying the graffitying of a nationalist monument as a surviving form of 
anti-nationalist brigandage, I want to mark ongoing southern contestations of Italian unification and hegemonic national identity in a contemporary cultural context. Read as such, these tactics of contemporary politico-cultural brigandage belie the notion that the South is 'nothing more than a forgotten victim, an inert mummy in the closet of others' fortunes’ (Buttafuoco quoted in Marzocco 2006: 25). On the contrary, situated within the historical genealogy of contestatory acts of brigandage, the defacing and spectacular resignification of a statute of Italy's iconic nationalist poet evidences a vibrant southern culture connected both to its insurrectionist past and to contemporary transnational counter-hegemonic cultural movements, such as African American hip hop culture. In this light, then, I situate southern graffiti and rap in a black Mediterranean-Atlantic.

\section{Provisional Street Justice: Southern Graffiti as Contemporary cafone Cultural Practice}

In his analysis of the politics of urban graffiti, Crimes of Style, Jeff Ferrell refuses to separate the aesthetic aspects of graffiti from its political significations. 'Graffiti,' he argues, 'resists not only authority, but the aesthetics of authority as well' (2001: 176). By politicising the aesthetics of authority, Ferrell brings into focus the political dimensions that drive the ongoing criminalisation of graffiti practice: 'Graffiti writing breaks the hegemonic hold of corporate/government style over the urban environment and the situations of daily life. As a form of aesthetic sabotage, it interrupts the pleasant, efficient uniformity of “planned” urban space and predictable urban living’ (2001: 176). Ferrell elaborates on the political significance of graffiti by pursuing its ramifications in terms of a crime of style: 'Graffiti writing thus constitutes a sort of anarchist resistance to cultural domination, a streetwise counterpoint to the increasing authority of corporate advertisers and city governments over the environment of daily life’ (2001: 176). I want to transpose Ferrell's anarchico-political reading of graffiti practice to a graffitied square in the urban centre of Naples in order to flesh out the politico-cultural valency of his thesis.

Via Toledo is Naples' grand promenade. Every afternoon the street is transformed into a bustling and dynamic space of social exchange, as throngs of people of all ages parade up and down its length. When walking up Via Toledo, a large semi-circular piazza suddenly opens up. A concave curve of buildings displaying the characteristic colours of Naples-Napoli red and Piperno grey_enframes the piazza. In the middle of this 
piazza stands a white marble statue of the Italian national poet, Dante (figure 1).

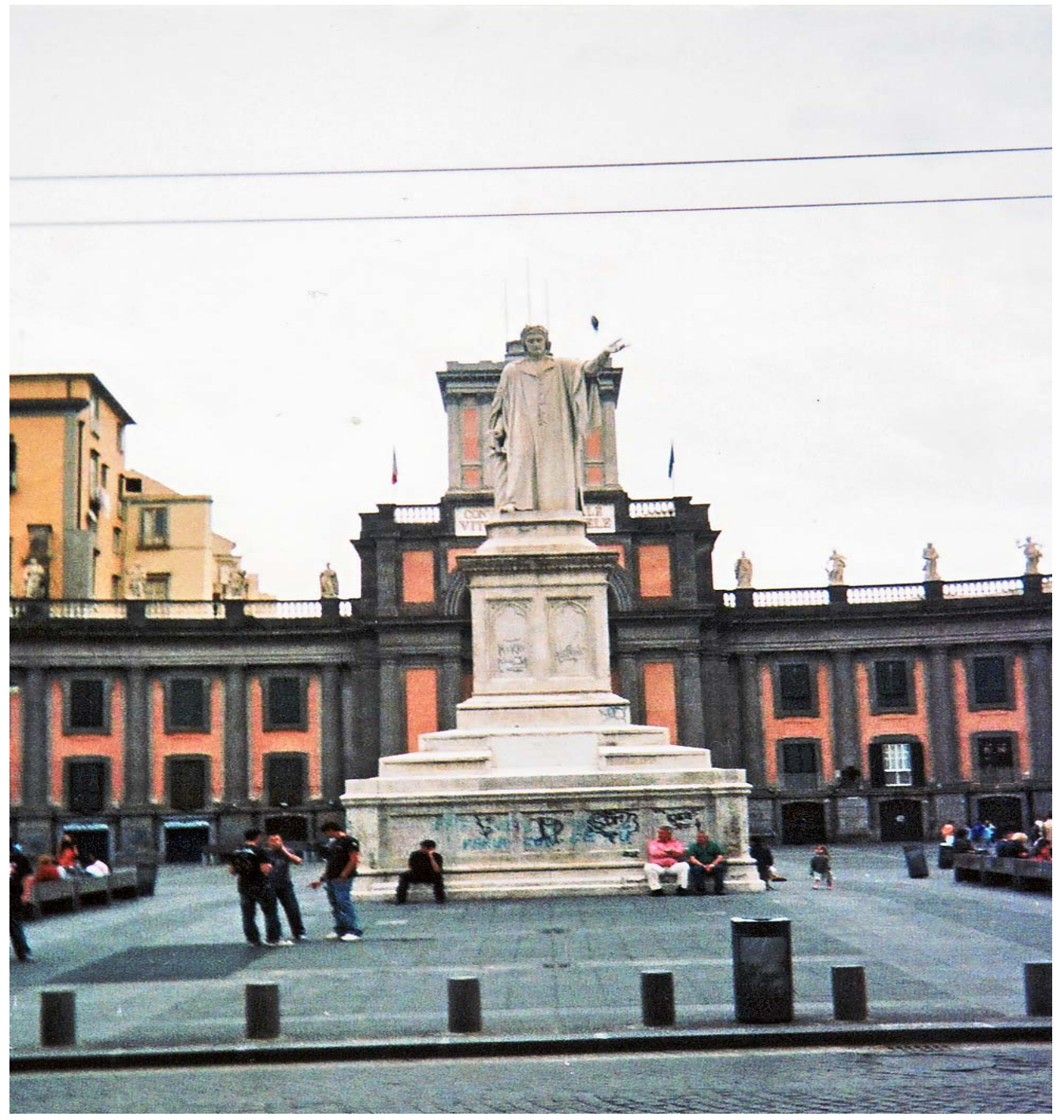

Figure 1: Piazza Dante, Napoli. ${ }^{2}$

Situated on a large white marble base, the poet raises a magisterial hand above the crowd and, in keeping with all traditional representations of Dante, his face is marked by a severe scowl (figure 2).

This poet of exile could not have been given a more damning space in the entire Italian peninsula. The iconic white figure, symbolising the purity of the Italian/Tuscan tongue, is here permanently dispatched to the miscegenated African-Oriental nether regions of the Italian nation-state. Swirling up from the very base of the statue is a Babel of languages that defies at every turn doctrinal impositions of cultural purity and linguistic

\footnotetext{
${ }^{2}$ All photographs of Piazza Dante, Napoli, are by the author.
} 
monoglossia. The Neapolitans have desecrated both the poet's call for a pure Italian language and the state's imposition of a hegemonic monolingualism, as embodied and petrified by the white stone figure. Palimpsests of languages, ciphers and tags are graffitied onto the statue's base, encroaching up to the very toes of the poet (figure 3).

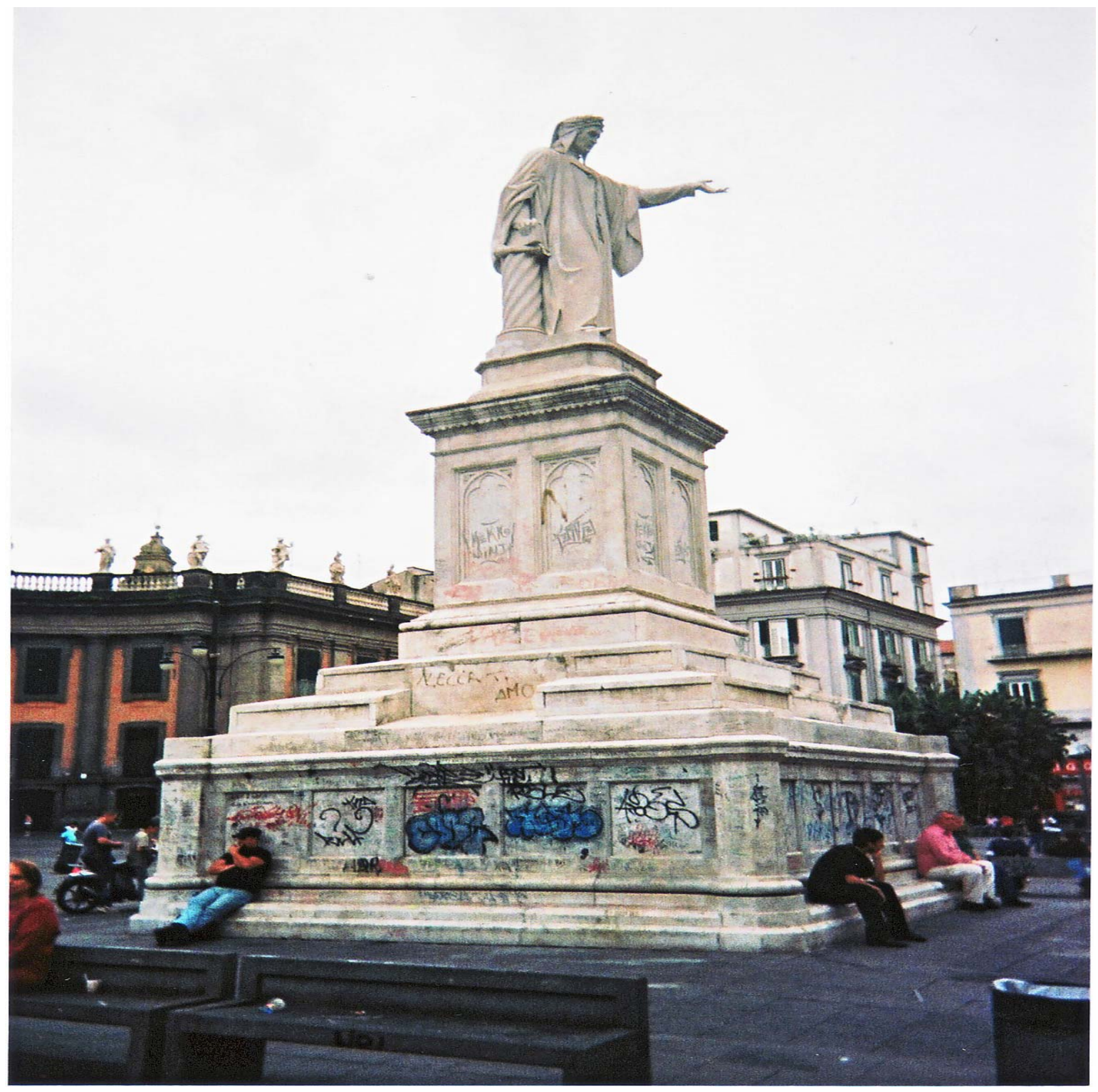

Figure 2: Statue of Dante, Piazza Dante, Napoli.

In contradistinction to the petrified stiffness of Dante, a vertiginous polyglossia spirals up towards this icon of the nation-state's doctrine of linguistic purity and univocality. Such unbridled polyglossia effectively mocks the poet's own strategy of celebrating, in his De Vulgaria Eloquio (c. 1307), all of the peninsula’s various 'dialects’ as having something to contribute to the 'Italian language.' After 1860, Dante’s ecumenical gesture is effectively exposed as a mere rhetorical ploy, for under the colonial regime of 


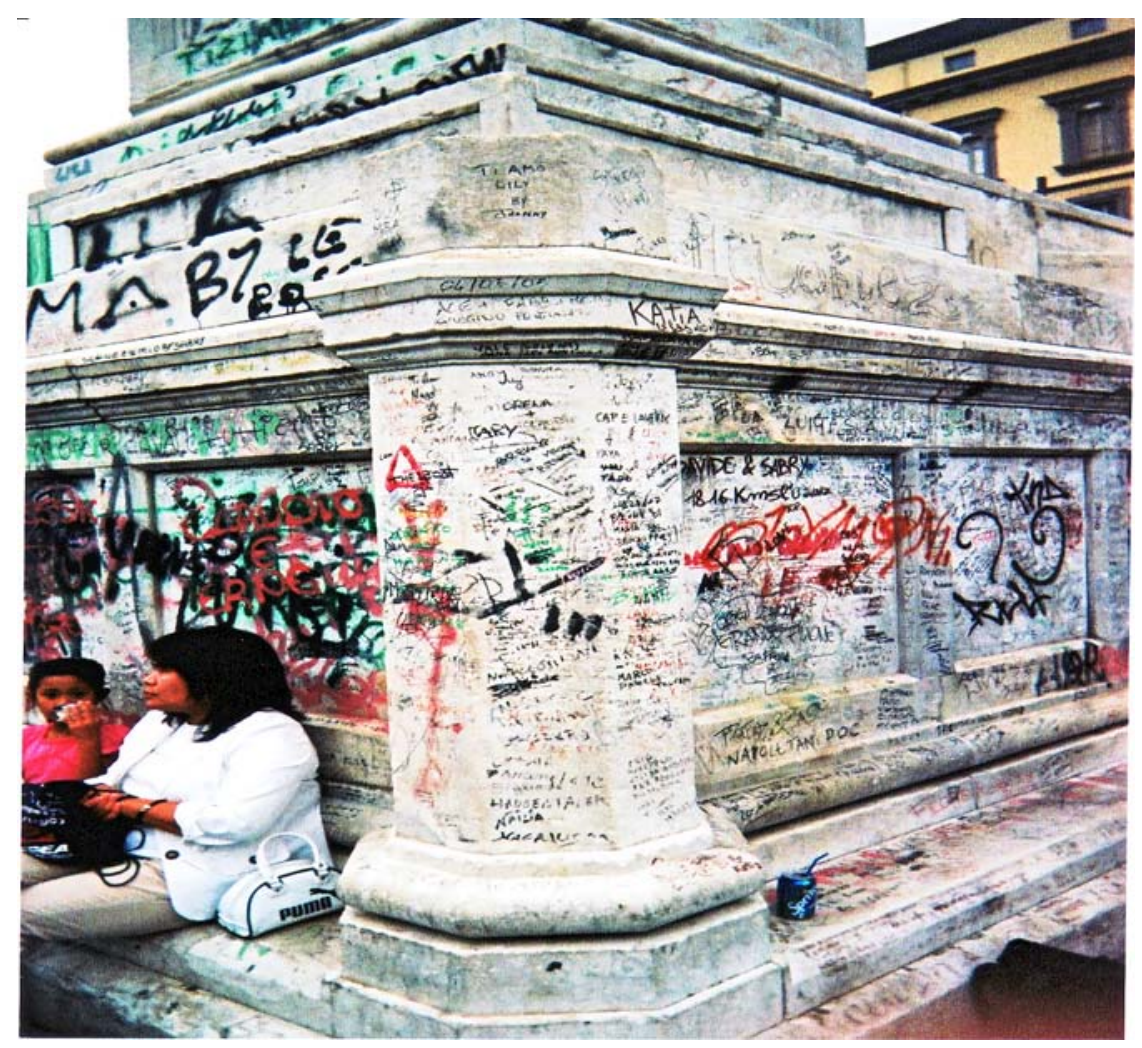

Figure 3: The base of the Dante monument, Piazza Dante, Napoli.

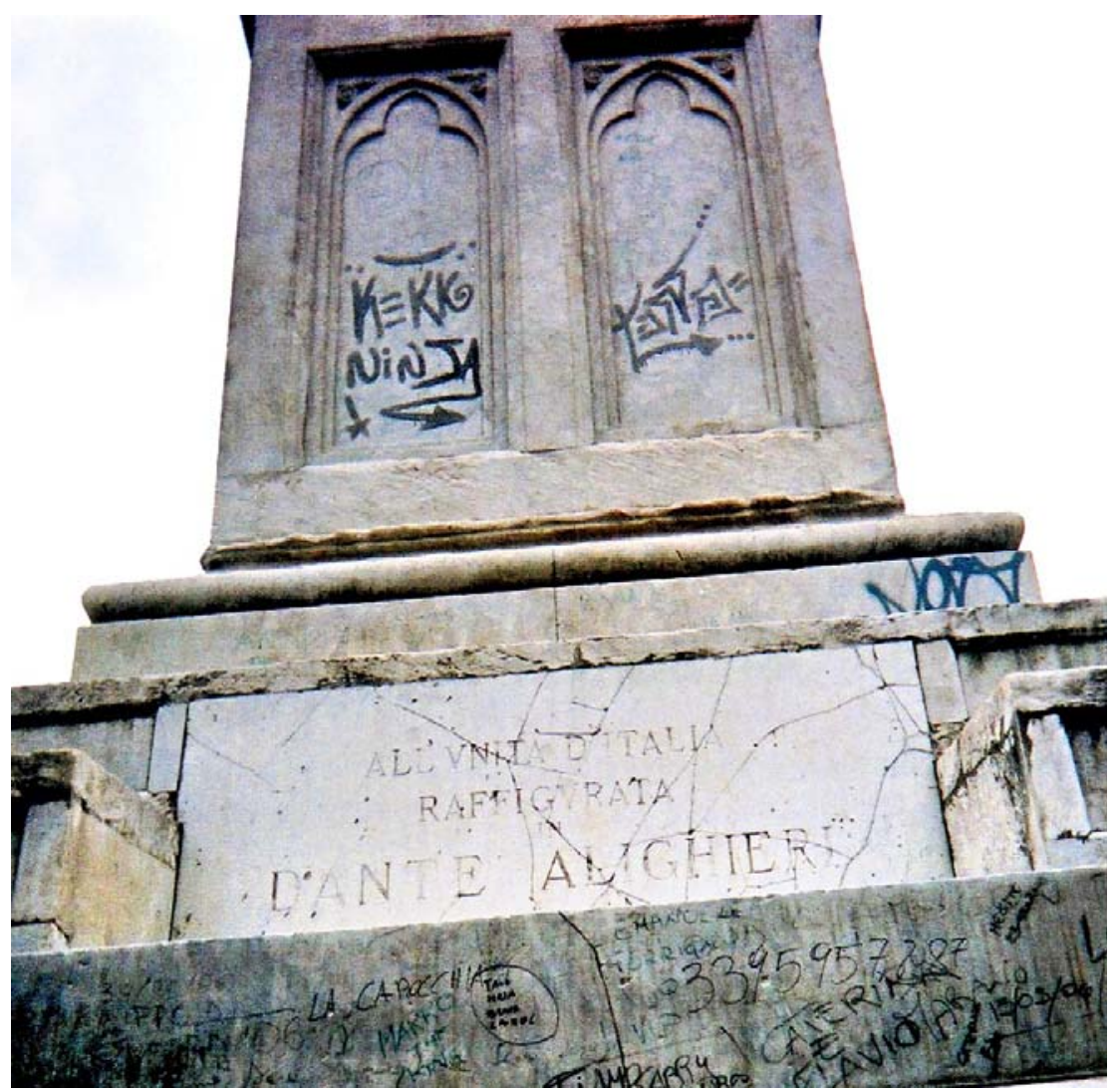

Figure 4: Plaque of the Dante monument: 'All' unità d'Italia raffigurata in Dante Alighieri' (To the unity of Italy configured in Dante Alighieri), Piazza Dante, Napoli. 
unification Tuscan becomes the state language, and all other regional languagesincluding Greek, Catalan, Albanian, Romany and Occitanic —and 'dialects' are effectively outlawed (see Lepschy, Lepschy and Voghera 1996: 72-73). This nationstate monument enunciates as much in the cartouche, which didactically declares the political significance of this northerner situated in this southern piazza: 'All' unità d'Italia raffigurata in Dante Alighieri' (To the unity of Italy configured in Dante Alighieri) (figure 4).

Up against this monumentalising and hegemonically monolinguistic gesture, the graffiti that inscribes Dante's statue must be read as an exemplary instance of linguistic heteroglossia, understood in the Bakhtinian sense of contestatory language use, which symbolically and literally ‘disses’ or disrespects Dante’s nationalist status and monologic authority through the 'uninterrupted processes of [linguistic] decentralization

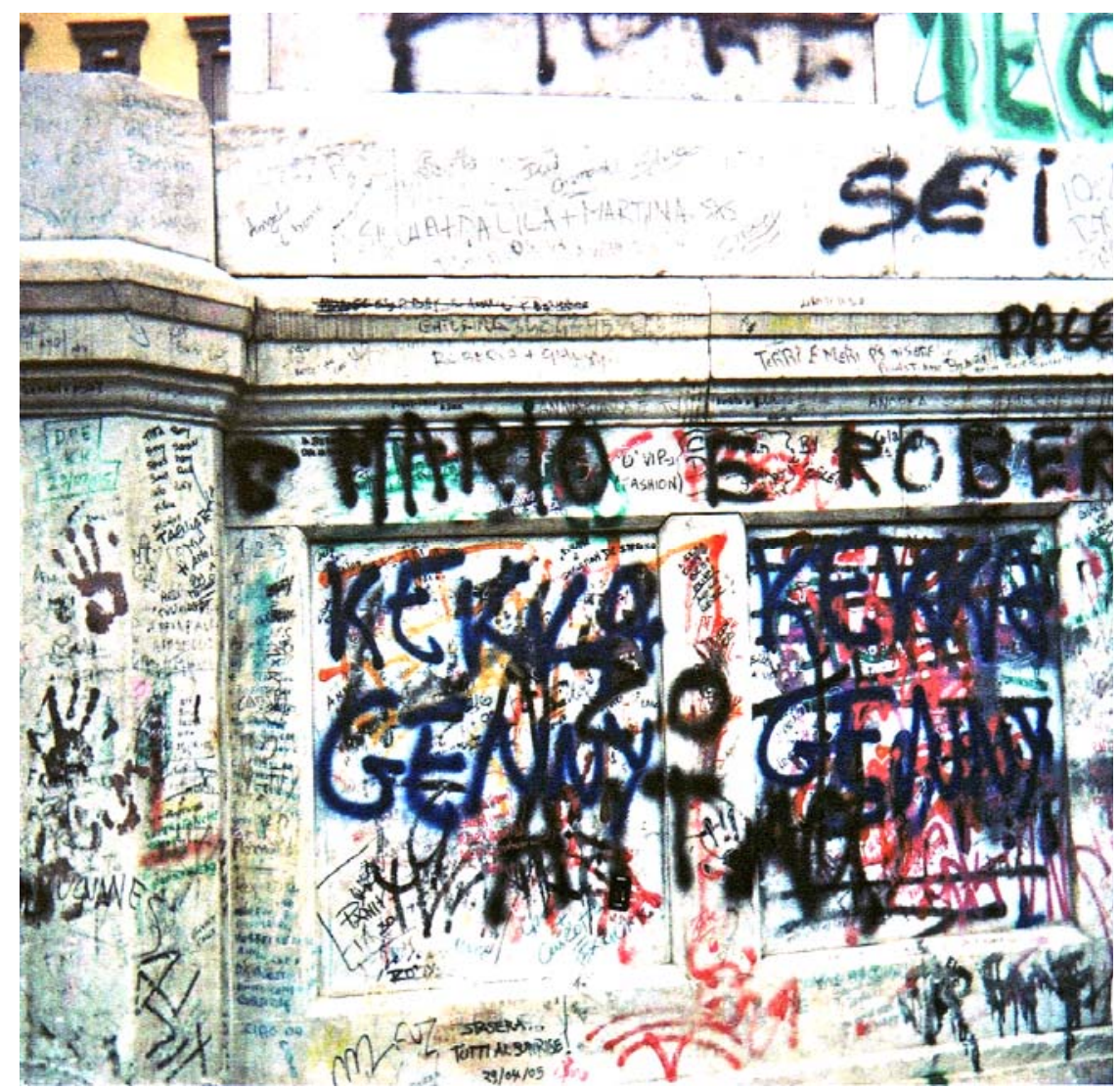

Figure 5: The ‘dissed’ Dante monument, Piazza Dante, Napoli.

and disunification’ (Bakhtin 1987: 272) (figure 5). The palimpsests of graffiti tags that inscribe the monument are graphic testimony to a 'social and historical heteroglossia' 
driven by 'centrifugal, stratifying forces' that contest and contradict the 'cultural, national and political centralization of the verbal-ideological world [of] the higher official socio-ideological levels’ of the unified nation-state (Bakhtin 1987: 273). Genealogically connected to their African American cultural roots, the multicoloured, multilingual tags marking this white monument metaphorise an other coloured Italy that belies the caucacentric fantasies of a pure white/European nation.

In his incisive analysis of subcultural practices, Dick Hebdige notes how subcultural practices are represented by the dominant order as 'noise' that generates disorder and chaos, in contradistinction to 'sound,' that reproduces the order and discipline of the dominant culture (1987: 90). Rather than viewing the graffiti in Piazza Dante in terms of 'noise' as opposed to 'sound,' I argue that the graffiti exemplifies its own type of 'sound,' which only makes sense when it is historically and geopolitically situated. Public space in Piazza Dante is mobilised by the nation-state through the use of this iconic statue, in order spatially and monumentally to establish its hegemonic coordinates of power. Located within the axis of hegemonic-nationalist knowledge/power, the graffiti on this monument can be seen as a form of politicocultural dissent that recalls the historical forms of southern brigandage as insurgent political practice, as mapped by Scarpino, De Jaco and Salera map in their critical analyses of the southern cafone/barbarians. The graffiti inscribing this nationalist monument reclaims public space by resignifying the dominant understanding of the term 'civic.' As has been lamented in much critical literature addressing the 'southern question,' the South is seen to lack civic spirit and a sense of public morality (Banfield 1958; Putman 1993; Galasso 2005, 34). I would argue, however, that this graffitied statue of Dante instantiates a form of civic culture that remains illegible for dominant culture, signifying only vandalistic 'noise.' This graffiti represents a form of grassroots civic culture that reorients the caucacentric, monoglossic nation-state space into a place that is coextensive with southern community histories, politics and cultural practices (figure 6). ${ }^{3}$

\footnotetext{
${ }^{3}$ Space precludes me from discussing in detail the spectacular manner in which the statue of Garibaldi in the Piazza Garibaldi, Napoli, has been graffitied in the same manner as the statue of Dante. This other Italian nationalist 'hero' of unification has been brilliantly resignified by Neapolitans. His statue now bears, amongst other things, a huge anarchist circle-A and five-pointed anarchist stars.
} 


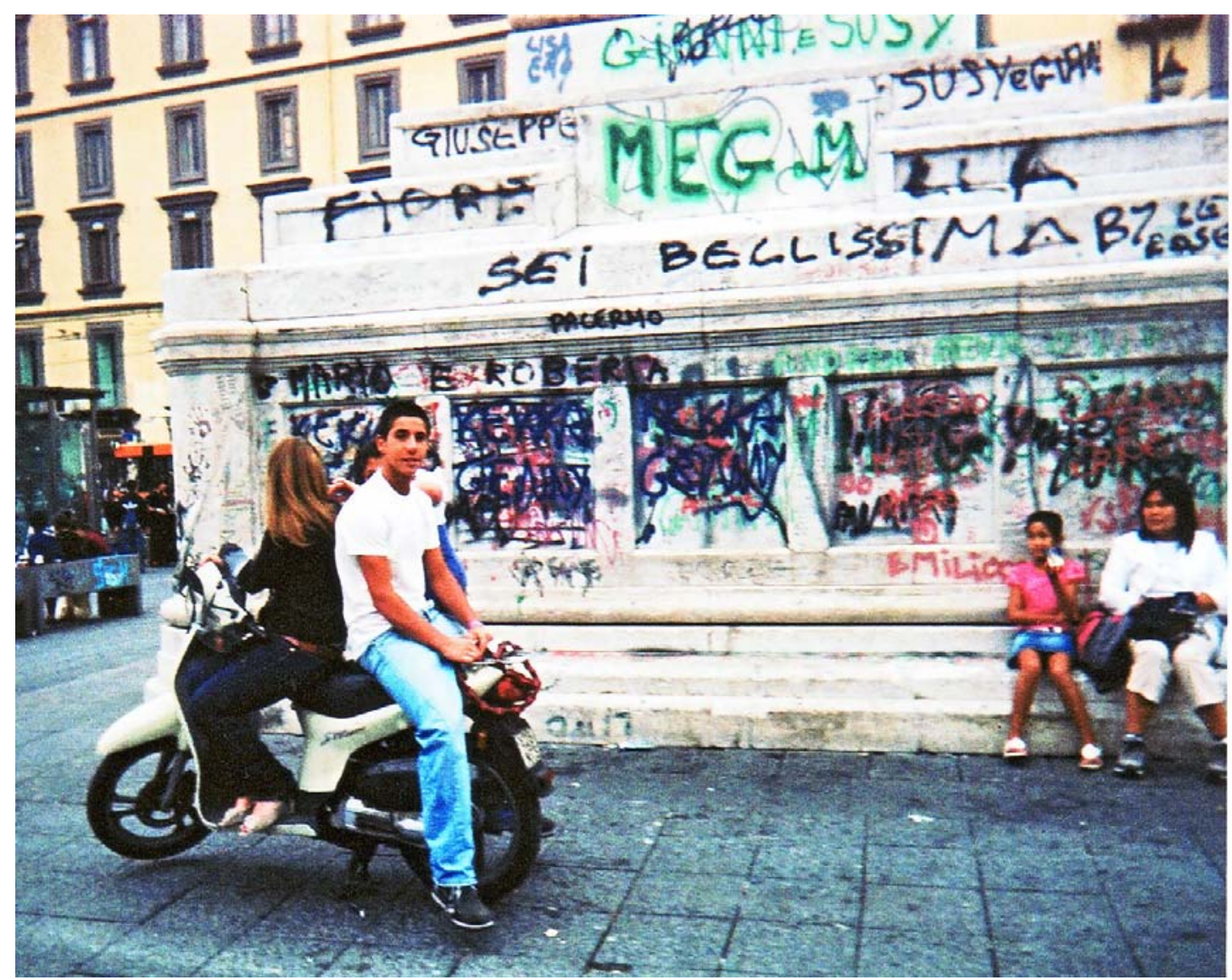

Figure 6: Piazza Dante’s graffiti resignifying hegemonic concepts of the civic.

The graffitied Piazza Dante, read in a hegemonic political frame, emerges as another example of the legendary uncivic and dirty nature of the South, captured in the northern slogan: ‘sudicio-Sud' (filthy-South). The Neapolitan hip hop group, Posse 99, sardonically articulates this northern view of unsanitary Southerners in their song 'Napoli':

\author{
Na-Na-Na- Na Napoli \\ Città dimenticata sfruttata abbandonata \\ da tutti disprezzata ma a Agnelli c’è piaciuto \\ 'o lavoro e' l'emigrato pacche scassate \\ famiglie disgregate e a Torino Milano \\ napulitano terrone e ignorante \\ magnate 'o sapone lavate cu'l idrante \\ Na-Na-Na-Na Naples \\ Forgotten city exploited abandoned \\ by everyone scorned but liked by Agnelli \\ to work the migrant, with shabby cardboard suitcases \\ families broken up and off to Turin Milan \\ ignorant Neapolitan terrone \\ eat your soap and wash yourself with the fire hydrant
}

Scorned by northerners as a filthy city, Naples is only appreciated by the likes of 
corporate bosses such as Agnelli, owner of the giant car manufacturing company FIAT, who draw on the South for cheap manual labour. The legendary ignorance and dirt of the terrone (a northern racist slur, largely deployed in the 1950s and 1960s, a period of mass southern migration to northern industrial cities, which targets Southerners as 'people of dirt, the dirt between one's feet') is satirised by Posse 99 in the Northerner's contemptuous order that Southerners, ignorant of basic sanitary practices, eat soap and wash themselves with fire hydrants.

Read within the contestatory history of the South, the graffitying of the statue in Piazza Dante transmutes the monolingual and culturally and racially sanitised space of the white nation-state into a community place hosting political rallies and protests, dance parties, buskers and activist performances. 'Clean buildings, and the appreciation of them,' Ferrell argues, 'are as much a part of authority and control as police patrols and prisons; and the markings of graffiti writers are as much a threat to this as are protest marches or rent strikes ... graffiti writing is an inherently political act, a crime of style entangled with the politics of authority and resistance' (1996: 184). Through the graffitied resignification of the monument to Italian unification in Piazza Dante, a different modality of the civic is enacted that remains unintelligible within dominant politico-cultural frames. The graffiti challenges both the pristine caucentricity that regards Italians-as-white and the raciological labour required to construct a white nation predicated on a subjugated and othered black-orientalised South (Pugliese 2002a, 2002b, 2007b, 2007c; Guglielmo and Salerno 2003). The multicoloured and multilingual tags inscribing this white nationalist monument signify in terms of so many celebratory metonyms for the polyglot ethnicities and cultures that, in fact, constitute the South. Through this graffiti, the ethnically, culturally and linguistically heterogeneous lived civic realities of the South are graphically marked and enunciated in public space.

The Neapolitan group Spaccanapoli, who in their music draw upon the crosscultural African and Arab roots of much music from the South, articulate the politico-cultural significance of Piazza Dante in their eponymous song:

Piazza Dante

E balla, e balla, e balla

Ca chi fatica nun sa juca a palla!

E canta, e canta, e canta

Ca chi è mariuolo ... campa e s'avanta ... 


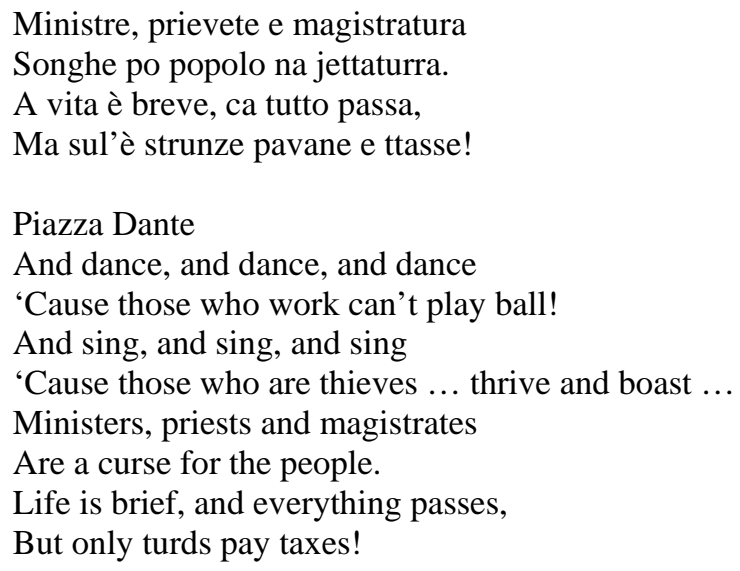

In Spaccanapoli's 'Piazza Dante,' the political, ecclesiastical and juridical power of the Italian nation-state, embodied metonymically by 'ministers, priests and magistrates,' is resituated in southern historical terms as a 'curse for the people.' This curse refers historically to the punishing taxation system imposed on the South by the northern-led nationalist government soon after unification. The taxation regime enabled the legalised sacking of the South. It effectively stripped the South of the significant financial reserves it held prior to unification and consequently disabled its economic prospects (Salera 2006: 477-86). Indeed, the expropriated monetary reserves that flowed into northern coffers were used to finance the industrialisation of the North (Di Fiore 2008: 186-87).

The graffitying of Piazza Dante exemplifies what Michel de Certeau eloquently terms the 'art of the "weak" against the "strong"' (1988: xix). In his reevaluation of the practices of everyday life, de Certeau differentiates between 'strategies' and 'tactics.' Strategies, he argues, are deployed by those in positions of power and privilege; they occupy 'proper' sites and are empowered by the resources of authorising institutions such as the government and law. In contradistinction, tactics are deployed by subjects who "cannot count on a "proper" (a spatial or institutional localization) ... the place of the tactic belongs to the other' (1988: xix). Disenfranchised in financial and political terms, tactics can only stage the provisional 'victories of the "weak" over the "strong", (1988: xix). Because they have no proper institutional base or authority, tactics can only ever secure fleeting victories. They temporarily subvert, but cannot overturn, dominant relations of power. The graffiti that inscribes Piazza Dante powerfully embodies de Certeau's contestatory concept of the tactic: it is the art of the politically and economically disenfranchised against the institutional power of the nation-state. Viewed 
in de Certeau's terms as the 'arts of operating' in the face of institutional power, the graffiti comprises a fragile, multilingual and graphic network of ‘antidiscipline’ (1988: $\mathrm{xv)}$ that, in contemporary form, makes reference to the South's history of insurrectionist and antidisciplinary brigandage (figure 7). As a form of antidiscipline, this graffiti can also be read as an 'antilanguage' that contests institutionally-sanctioned understandings of civic and cultural practice.

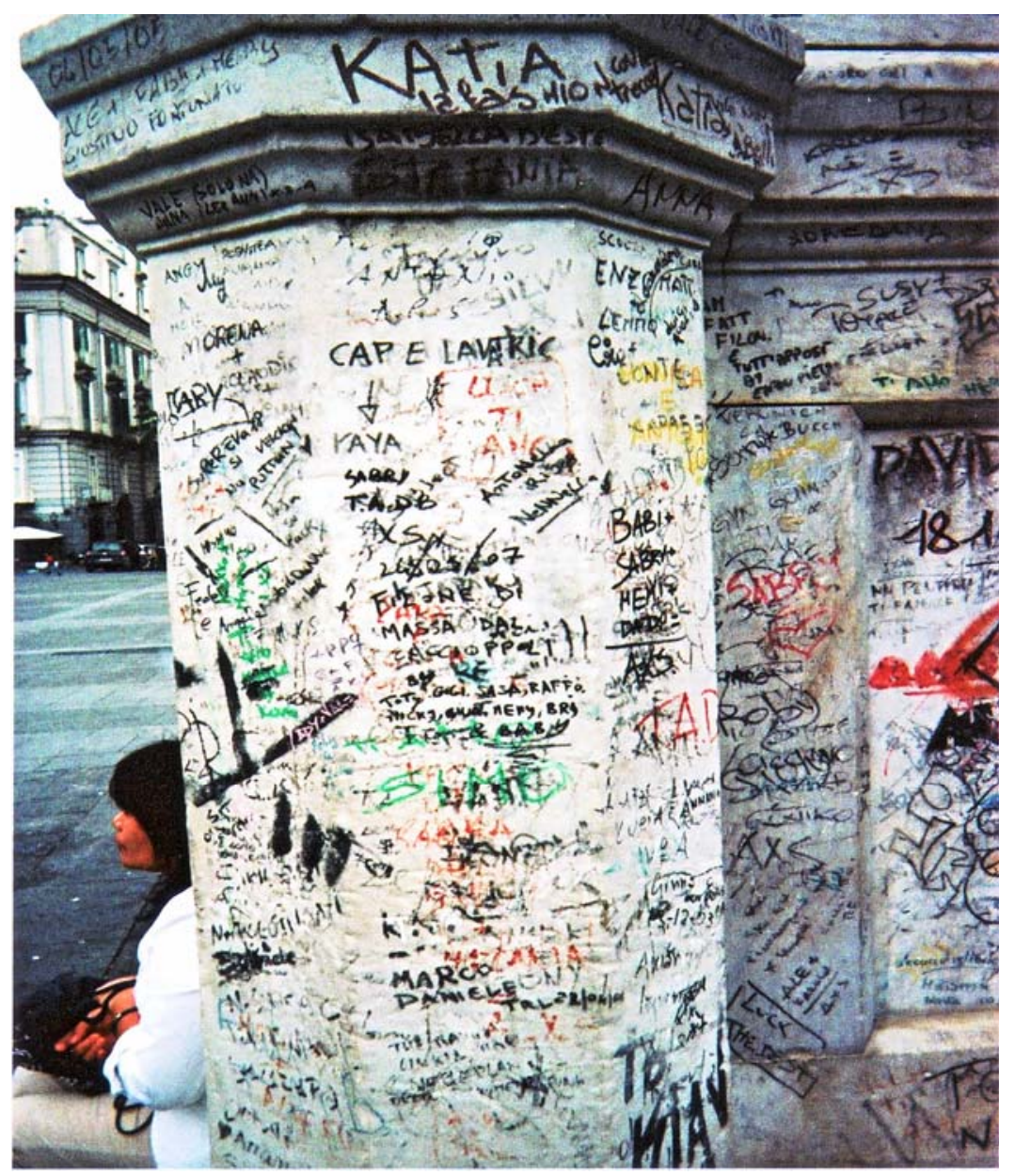

Figure 7: The polyglossia that inscribes the Dante monument.

The visual and kinesiological resignification and reclamation of Piazza Dante by various communities, including graffitists, activists, buskers and performers exemplifies what Ferrell brilliantly calls 'provisional street justice' (2001: 38). This refers to the tactical, and thus provisional, reclamation by communities of urban space through cultural practices such as graffiti, dance parties or aural and kinesiological occupation of public spaces not officially designated for entertainment purposes. 

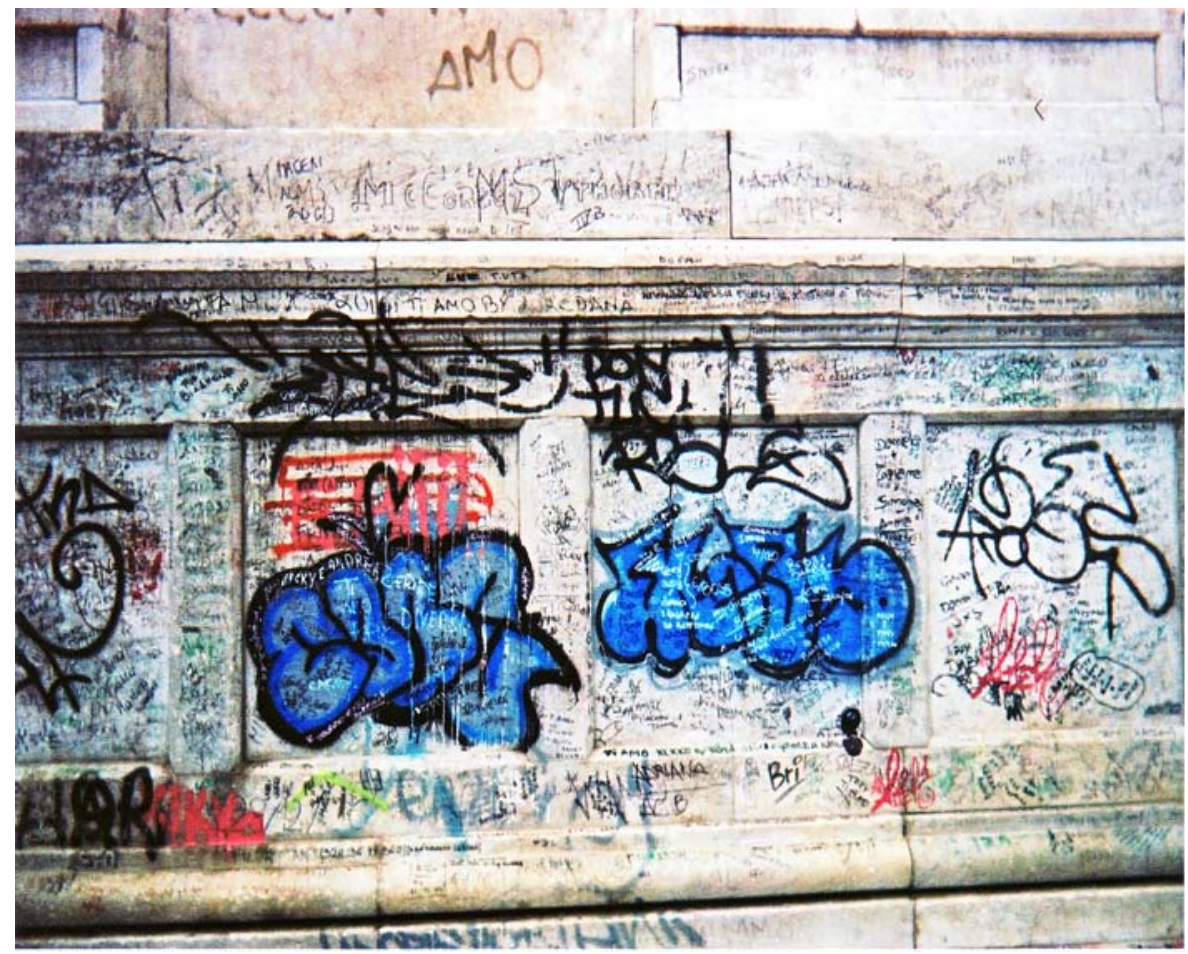

Figure 8: The graffiti in Piazza Dante as provisional street justice.

The provisional street justice enacted in Piazza Dante powerfully evokes the anarchic and insurrectionist practices of southern brigandage, which, as politico-cultural practices of antidiscipline, were scattered, transitory and always performed on the roads and streets of the South. The dance parties, protests and activist performances staged in this culturally reclaimed public square bear testimony to the fleeting victories of communities that have no 'proper' institutional base. The exhortation by Spaccanapoli to 'dance, dance, dance' and 'sing, sing, sing' in Piazza Dante because 'life is brief, and everything passes,' encapsulates the ephemeral nature of the politico-cultural tactics performed in the square.

\section{Black Mediterranean-Atlantic: Transnational Flows and Transcultural Crossings}

The African American development of hip hop in the USA in the early 1970s saw the flourishing of three interrelated cultural forms: graffiti, break dancing and rap (Toop 2002). I mark the particular interrelation between African American graffiti practice and rap in order to delineate the transposition of hip hop, 'that most diasporic of cultural forms' (Gilroy 1993: 34), to the southern Italian context. The late 1980s and early 1990s saw the enthusiastic uptake by southern musicians of African American hip hop (Sciorra 2007). Drawing upon the politically contestatory dimensions of the genre (Kitwana 2002), southern musicians began to deploy rap in order to critique the racist history of 
post-unification Italy (Mitchell 1996, 2000; Dawson and Palumbo 2005; Sciorra 2007). The use of local dialects and regional vernaculars in southern rap underscores the political and heteroglossic contestation of nationalist monolinguism and monologia. It signifies, in Tony Mitchell's analysis of regional vernaculars in southern rap, 'an act of defiance' (2000: 49).

Through the interlacing of African American rap with the folk music traditions of the South, southern rap articulates transoceanic connections between the black Atlantic and the black Mediterranean. Southern rap exemplifies, in Paul Gilroy's terms, the politicocultural ability to 'transcend both the structures of the nation state and the constraints of ethnicity and national particularity’ (1993: 19). Musically, the folk traditions of the South are inscribed with the legacies of North African, Middle Eastern and Arab crosscultural exchanges. In other words, southern rap confirms both a transatlantic connection with African American culture and a transmediterranean reconnection with African and Arab culture. The Nuova Compagnia di Canto Popolare, Nour Eddine and Phaleg, Almamegretta, Posse 99, the Nuovi Briganti and Eugenio Bennato embody this type of transoceanic cultural connection and reconnection. The Sicilian rappers, Nuovi Briganti, in their 'Sono siciliano' (I Am Sicilian), identify and name this black transmeditteranean-atlantic southern culture:

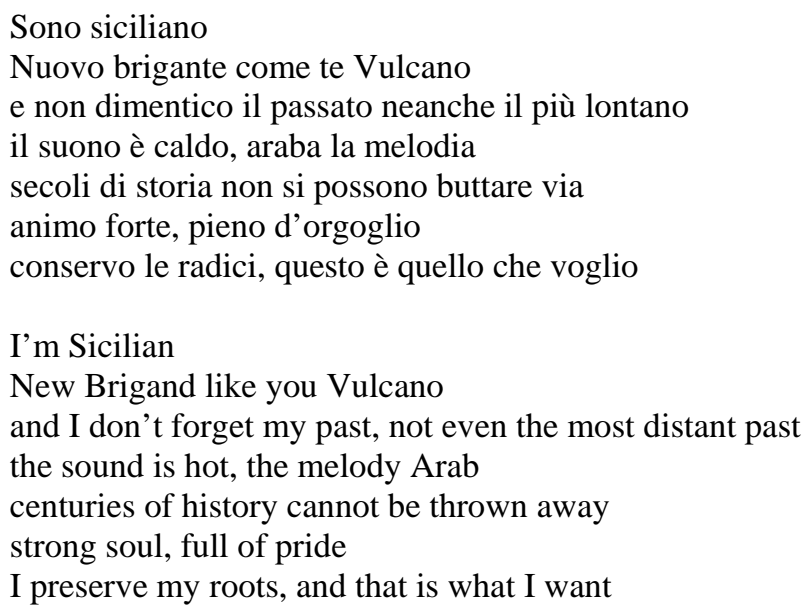

The Nuovi Briganti here acknowledge the rich Arab history of Sicily as culturally constitutive of the island's identity. In opposition to the contemporary Arabophobia of Northern Europe, the Nuovi Briganti embrace, reclaim and celebrate their Arab roots. ${ }^{4}$

\footnotetext{
${ }^{4}$ On the South’s contemporary reclamation of its Arab history, see Pugliese (2007b).
} 
Similarly, Eugenio Bennato, in his Grande Sud and Che Il Mediterraneo Sia, interlaces southern vernaculars with soloists who sing in the languages of Morocco, Tunisia, Ethiopia, Mozambique and Madagascar. Bennato’s polyglossic intermixing of southern vernacular and Arab and African linguistic and musical texts powerfully metaphorises the musical equivalent of the graffitied Piazza Dante. 'All frontiers,' sings Bennato, 'are all the same/completely antimusical.' Bennato calls for the overthrowing of Fortress Europe through a music that 'doesn't have a passport' and that doesn't care 'if it's alien or illegal' (Che il mediterraneo sia).

These crosscultural flows are not only materialised through the intermixing of heterogeneous musical styles; they are evidenced in the lyrics of the songs. In their 'Fottuto terrone' (Fucked Terrone), the Nuovi Briganti articulate the ongoing racism of northerners towards Southerners and Southerners’ solidarity with black Africa:

\author{
Etichettato terrone \\ da quell'ignorante di un razzista \\ nordista sporco leghista \\ convinto della sua italianità \\ che si traduce in ottusità \\ chiamandomi africano... \\ Chi è puro, cosa è puro \\ il continentale? ... \\ amico qua la mano \\ solidale con l'uomo africano \\ sono un fottuto terrone fiero

\section{Labelled terrone} \\ by that ignorant racist \\ dirty northern leaguist \\ convinced of his Italianness \\ that translates into obtuseness \\ calling me African... \\ Who is pure, what is pure \\ the Continental? ... \\ friend give me your hand \\ solidarity with the African \\ I'm a proud fucked terrone
}

In the wake of the waves of migrants from Africa and the Middle East who have come to Italy over the last three decades searching for a livelihood, northerners have coined the neologism sottoterrone ('sub-dirt beneath one's feet') to label this new non-white population. At work here is a recalibration of racial hierarchies that effectively functions to reposition targeted racialised subjects on the vertical scale governed by whiteness as the normative standard. In tandem with the entry into the Italian nation of people of 
colour from Africa, the Middle East and Asia, the racialised extraneity of Southerners has also been somewhat recalibrated. They no longer constitute northern Italy's absolute other; rather, this position has been assigned to those non-European subjects geopolitically extraneous to the body of the nation. I say 'extraneous' as they have been designated by Italians as extracomunitari, that is, as people from outside the racially circumscribed national 'community.'

As I have discussed elsewhere, a similar phenomenon of racial recalibration of Southerners occurred in the contemporary Australian context soon after the elimination of the exclusionary White Australia policy in the early 1970s and the entry into the country of migrants from Asia, the Middle East and Africa. The presence of these nonEuropean immigrants moved Southern Europeans (such as Italians and Greeks) up the white supremacist racial hierarchy toward what I term 'proximate whiteness' (Pugliese 2007a: 30). Proximate whiteness refers to the fact that although many Southern Europeans fail, in phenotypical terms, to 'look' white, the presence of non-European immigrants allows them to be brought, politically and bureaucratically, into the proximate fold of whiteness.

In 'Fottuto terrone,' the Nuovi Briganti mark northern Italy’s anti-southern history whilst simultaneously interrogating Fortress Europe's contemporary concern to preserve its white 'racial purity.' In response to these ongoing racialised factors, the Nuovi Briganti establish lines of solidarity with Africa that cut across racist borders and interdictions. In marking these forms of southern solidarity with Africa, I do not wish to suggest that they are homogenously representative of the South. On the contrary, again as I have argued elsewhere, the South is marked by its own internal history of racism, racial hierarchies and violent exclusions (Pugliese 2007b). Perhaps nothing more graphically exemplifies this than the damning report released in 2007 by Medici Senza Frontiere, the Italian branch of Médicins sans Frontières, called Una stagione all'inferno (A Season in Hell) (2007). Based on field research conducted between June and November 2007, the report examines the exploitative, unsanitary and, in some cases, life-threatening conditions endured by seasonal workers from the Global South (Africa, the Middle East and South-East Asia) who live and work in the seasonally-oriented agricultural sectors of Italy's South. In their Introduction, the authors of the Report draw attention to the manner in which: 
the national and local institutions seal their eyes, ears and mouths in the face of the massive exploitation of foreigner workers who labour in the agricultural sectors of the South, precisely because they are seen as crucial to the sustainability of the local economies. The use of forced labour at minimal costs, black market recruitment of labour, the negation of basic and decent living conditions, the lack of access to medical care-all these things are well known and tolerated. The mayors, the State bodies, the inspectors of work conditions, the associations devoted to worker protection, the ministers: all know what is going on and all remain silent. (2007: 2)

This Report challenges any facile view of an undifferentiated South acting in solidarity with immigrants of the Global South. Rather, it brings into sharp focus the violent racialised relations of geopolitical and economic power that cut across the Italian peninsula and its islands. Those relations inscribe and reproduce the most destructive effects of globalisation-understood, in this context, as the geo-politico-economic process predicated on reproducing violently asymmetrical relations of power founded, in part, on racialised systems of discrimination, exclusion and exploitation.

I opened this essay by situating the insurgent practices of Southerners during the war of Italian unification in the context of the Cafona War. As a result of the violent imposition of northern colonial rule on the South during the period of Italian unification, brigandage emerged as a tactical contestation of the North's annexation and consequent expropriation of the South. In naming themselves the 'New Brigands,' the Nuovi Briganti reflexively assume ownership of the South's use of brigandage as a modality of contestatory politico-cultural practice. In their 'Unificazione $=$ Falsificazione' (Unification $=$ Falsification), they explicitly situate their politico-cultural interventions within this violent genealogy:

Tre kilometri di mare ci separano dall’Italia ma è maggiore la distanza per la nostra storia 1861 è l'unificazione io mi domando: realtà o finzione?

Garibaldi schiavo del potere prima sobilla e poi fa massacre grandi masse di siciliani ribellati. Vittorio Emanuele li ha condannati. Via Borboni nuovi padroni ci son nuove tasse ma tutto è lo stesso. L'acqua scarseggia, dura è la terra poco mangiare è peggio che in guerra. Anafalbetismo nella folla tutti contro tutti, è perso chi molla e intanto si lavora su al settentrione strade, ferrovie, industrializione

Three kilometres of sea separate us from Italy but the distance is greater for our history 1861 is the unification 


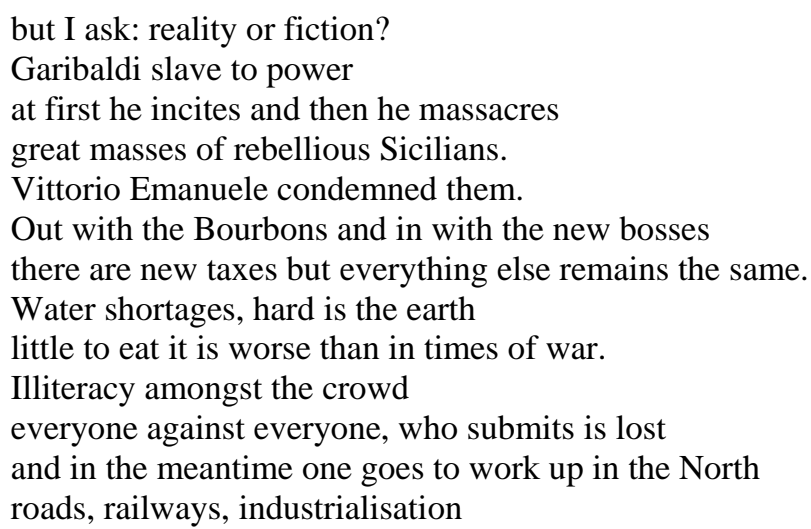

By situating themselves within a southern genealogy of anti-nationalist brigandage, the Nuovi Briganti refuse to romanticise contemporary southern transmutations of brigandage into the deadly forms of the Mafia, 'Ndgrangheta and Camorra. In the closing lines of 'Unification = Falsification' they condemn these contemporary forms of brigandage as yet another form of organised violence that is destroying the South:

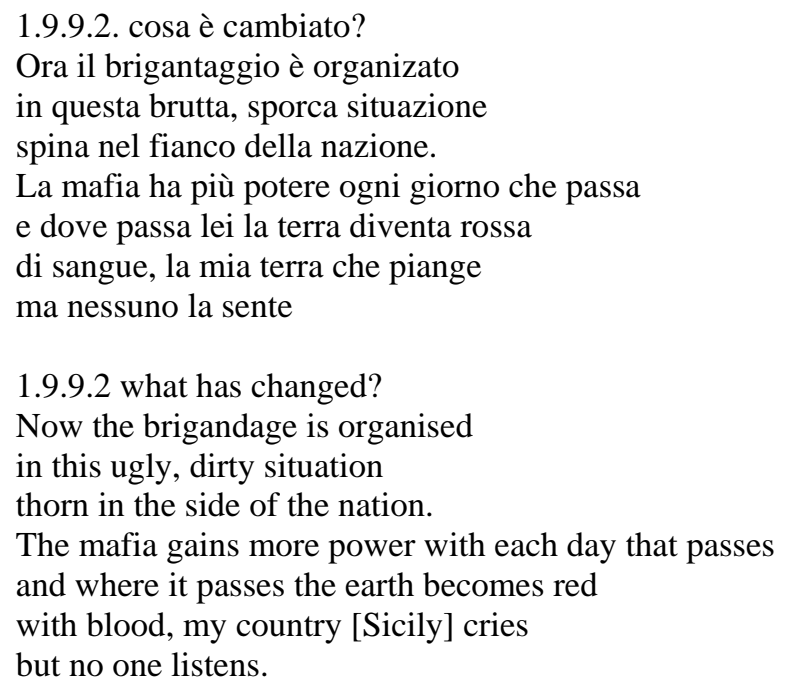

No one has more graphically or movingly captured the exorbitant violence visited upon Southerners by the mafia than the Sicilian photographer Letizia Battaglia. In a series of unflinching photographs, Battaglia (2006) has documented the unvarnished, violent and brutalising reality of life under the regime of organised crime, a regime that the Nuovi Briganti also reject.

\section{'The White Race has to Defend Itself': Blackening Italy and the Feral Beauty of Provisional Street Justice}

Since the 1970s, Italy has been transformed from a country that exported immigrants en masse to a place marked as a key migrant destination for people from the Global South 
(Turco 2006; Mezzadra 2007). Responding to the increasing flows of non-European migrants, particularly from North Africa and the Middle East, xenophobic media reports and articles have drawn attention to the threat posed by these immigrants to Italian civic culture and national identity. Writing in one of Italy’s leading newspapers, La Stampa, the sociologist Luciano Gallino vigorously condemns the increasing number of migrants entering the nation and the lack of legislative controls to screen and reduce this flow. Gallino focuses in particular on what he perceives to be the negative effects of nonEuropean (that is, non-white) migrants on Italian culture:

In many Italian cities the signs are already manifest of a worrying degradation of the social fabric and of the urban spaces that is now without parallel in any other nation within the European community. Whether or not you'd like to hear this, this is connected in many ways to the uncontrolled flow of migrants .... The signs of their uncontrolled arrival are entire streets transformed into ugly copies of the suk of Marrakech, like Via Indipendenza in Bologna; entire parks that have fallen into the hands of drug-dealing migrants, like the Valentino in Turin; squares and streets and public places in which, at certain hours, a non-immigrant fears to set foot, such as the surrounds of Stazione Termini in Rome. (Quoted in Einaudi 2007: 147)

Gallino concludes his call for urgent legislative measures of immigration control by arguing that the increasing incursion of non-European migrants poses a 'threat of the greatest order.' Gallino’s public call soon became a chorus that culminated, in September 2002, in the passing of the draconian anti-immigration Bossi-Fini law that

mandates that foreigners secure a contract for employment in Italy before they are granted a residency permit. In order to obtain official documents, immigrants have to agree to be fingerprinted, suggesting that the state regards all immigrants as potential criminals .... The rights of legal immigrants, who are now tied to their employers by threat of deportation should they lose their jobs, are also dramatically curtailed by this law. (Dawson and Palumbo 2005: 166)

As Ashley Dawson and Patrizia Palumbo argue, this anti-immigrant legislation is structurally contradicted by a growing presence of undocumented immigrant labour:

it is in the interest of the capitalist economy in general to maintain high levels of immigrant illegality and the draconian policing measures that ensure such illegality. For if immigrants are illegal, they can only accept 'black' work, which, of course, is by definition poorly paid. So-called clandestine immigrants therefore constitute a reserve army of superlative 'flexible' subjects, a juridically nonexistent labor force with no recourse to any of the legal protections or forms of collective bargaining that citizenship guarantees. (2005: 175)

Noting the exploitative juridico-economic double-logic that Dawson and Palumbo map, which powerfully impacts on the lives of undocumented immigrants, I want to focus on perhaps the most vulnerable and 'flexible' of subjects in this group: the itinerant hawkers from the Global South who toil in the streets and squares of Italy's metropolitan cities. I discuss this group of workers in relation to two intersecting 
racialised axes, politico-economic and cultural, which bring into contemporary perspective many of the key issues regarding the South raised in this essay.

These itinerant hawkers are collectively identified by Italians as vu cumprà or marocchini. Vu cumprà translates into the question 'do you want to buy?’ Itinerant hawkers address this question to prospective customers as they carry their loads of goods, such as sunglasses, bottles of mineral water, umbrellas, scarves and souvenirs. Vu cumprà is marked by the 'corrupted' use of Italian (vuoi comprare?), marking the speaker's outsider status and her or his purportedly congenital inability to master a European language. As such, vu cumprà is used by Italians as a racist slur. Most of these itinerant workers come from Africa, notably Libya, Morocco, Algeria, Tunisia, Sudan, Egypt, Somalia, Cape Verde, Eritrea and Mauritius. Given those origins, marocchini (Morrocans) has thus become a racist generic that conveniently erases ethnic difference by bringing together a diverse group of people under the homogenising imprimatur of a sign that signifies, negatively, 'blackness' and 'African.' In keeping with the historical contingency and mobility of racist descriptors, vu cumprà has been largely replaced in the Italian vernacular by marocchini. Furthermore, the goods and services offered by these itinerant workers are categorised by Italian economists and sociologists into the genres of 'parasitical services' and 'just in time.' 'Parasitical services' refers to jobs not requested by the customer, such as the washing of windscreens at intersections or the opening of doors, and 'just in time' refers to the appearance of these itinerant workers in front of hotel doors or tourist sites with umbrellas, for example, if it suddenly starts raining (Einaudi 2007: 92).

In his groundbreaking analysis of the colonial and imperial underpinnings of liberalism as a foundational western political practice, Uday Mehta demonstrates how western liberal theorists in the nineteenth century 'cast their gaze' on those non-western subjects who appeared 'unfamiliar' or 'strange,' and designated 'those life forms as provisional' (1999: 191). By viewing non-western lives as provisional—that is, 'incomplete, static, backward'—such lives were violently inserted by European powers into imperial teleologies that would ensure their assimilation into western norms: 'That judgement of other peoples' experiences as provisional—and the interventions in their lives that it permits - is the conceptual and normative core of the liberal justification of the empire' (Mehta 1999: 191). Incomplete, static, backward—such terms framed the South as 
Italy’s non-European other and justified the colonial project of unification. Southern lives, languages and cultural practices were viewed as merely provisional in relation to the transformative teleology of northern-imposed unification. On the larger, extranational geopolitical stage, this viewpoint also enabled seventy years of Italian colonial intervention, expansion, occupation and rule in North Africa (Del Boca 2002, 2005, 2007).

In the current context, the terms marocchini, vu cumprà, and just in time unequivocally position these itinerant workers in contemporary western-liberal nation-states such as Italy as having wholly contingent and provisional lives. The situation of such workers, however, is more drastic than that experienced by Southerners. After unification, southern Italians were at least inserted into an eschatological narrative of teleological progress and future transformation as prospective pseudo-Italian citizens. The itinerant workers of the Global South, however, are positioned as permanent interlopers, extracomunitari, who can only occupy a provisional status that holds no prospect for the legal uptake of citizenship and its attendant rights and privileges. The provisional status of itinerant workers from the Global South is most acutely demonstrated by the fact that, as economically and politically disenfranchised subjects, they are forced to find shelter and to construct makeshift homes in the cemeteries on the outskirts of Italy's metropolitan cities (Einaudi 2007: 133). Inhabiting empty burial vaults, these unauthorised workers literally embody the haunting category of the 'living dead.' As Mezzadra argues, what is instantiated here are racist formations predicated on the 'hierarchical ordering of different living bodies within a given territory, to the point of legitimating true and proper forms of segregation’ (2007: 26).

What possibilities of agency are available in the face of legislative exclusion and its physically and symbolically violent effects? One answer is provisional forms of street justice. As I have argued elsewhere, the migrant flows from the Global South to the Italian peninsula are staging the returns of the South's Souths (Pugliese 2007b). African and Middle Eastern returns, in which complex historico-cultural lines between the South and its Mediterranean neighbours are re-connected and re-articulated, cannot be countenanced by the Northern League and its racial fantasy of a pure white nation. For example, Ermino Boso, a Member of Parliament for the white supremacist Northern League, advocates 'the use of excessive force against immigrants. He "looks to defend 
white people from blacks,” because, “today, everyone is against the whites. The white race has to defend itself, because white faces are becoming extinct”' (quoted in Gold 2003: 85). The contemporary northern Italian fear that whites are at risk of being overthrown by people of colour evokes a racist/eugenicist history that stretches back to Cesare Lombroso in the nineteenth century. In his L'Uomo Bianco e l'Uomo di Colore [1871] (The White Man and the Coloured Man), Lombroso raises the question as to 'whether we whites, who proudly stand at the summit of civilisation, will one day bow our foreheads before the protruding lips of the Negro and the yellow and earthy face of the Mongol' (quoted in Pugliese 2002: 156). The paranoiac sense of white people under siege and facing the possibility of extinction due to the increasing presence in the Italian peninsula of people of colour is graphically captured in one of the 2008 election posters of the Northern League (see figure 9).

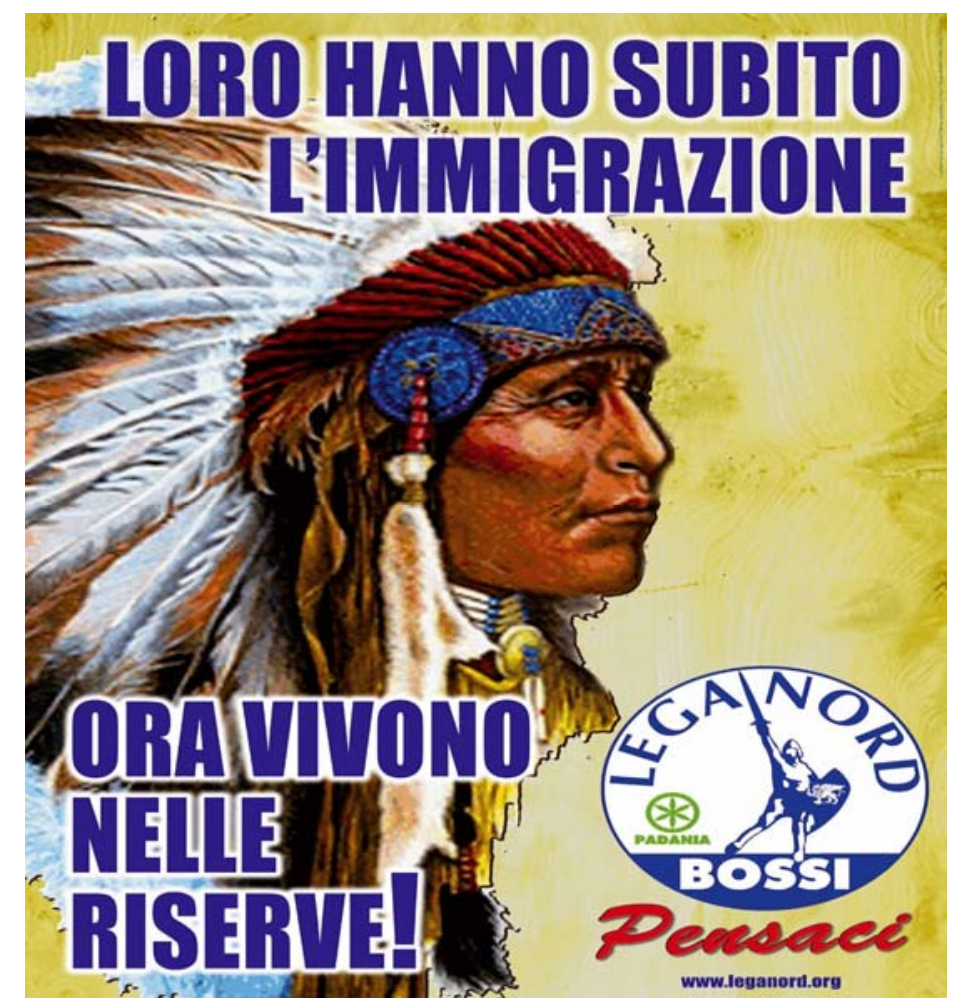

Figure 9. Lega Nord 2008 election poster, available at http://leganord.org/elezioni2008/politiche/manifesti_elletorali/Indiano\%2riserve\%20immigrazione\%0eltt 08.gif.

Depicting the head of a traditional Native American Indian, the text of the poster states: 'They have suffered immigration. They now live in reserves!' The colonial disavowals and ironies in this poster are multiple. Arrogating the subalternised position of Native Americans who have suffered centuries of colonial expropriation, attempted genocide 
and displacement, the League here frames privileged northern white Italians as a race that is now vulnerable to the same acts of violence experienced by native Americans. Here, however, the vulnerability arises because of the entry into the nation — and this, of course, is the sub-text—of immigrants of colour. In this poster, Italy's own colonial history of expropriation, attempted genocide and sequestration of indigenous African people in camps and reserves during the course of its African colonial campaigns, is resoundingly disavowed. Ironically, the totemic head of a tribal Native American evokes the spectre of the 'Doomed Race' theory that, in Social Darwinist terms, explained the 'inevitable extinction' of many Indigenous peoples before the superior white race. As the poster foments fear and reveals an unresolved post-colonial anxiety about the inhabitants of Italy's former colonies now coming home to roost, it implies the frightening possibility that the former colonial slave will now usurp the position of the colonial master.

Yet another level of political irony is inherent in the Northern League election poster. While its xenophobic text generates the fear that white Italians are at risk of becoming a subalternised minority that will be placed in camps and reserves, the violent reality of what is occurring in the Italian peninsula and its islands is effectively effaced. The poster occludes the fact that undocumented immigrants are being rounded up and incarcerated in Italy’s Centri di permanenza temporanea or Cpts (Centres of temporary permanency), legislated into existence under the infamous Turco-Napolitano Act of 1998. Cpts were initially established as centres in which refugees, asylum seekers and undocumented immigrants could be detained whilst they underwent official checks with regard to their identities. However, because these centres were given powers to detain their captive subjects, they were necessarily modelled on prisons (Einaudi 2007: 275). The European Union's Commission for Civil Liberty and Justice report on Italy's Cpts has condemned the centres for violating basic human rights at virtually every level and has called for their closure (la Repubblica.it 2008; Pugliese forthcoming). The racist anti-immigrant politics represented in this Northern League election poster are thus not the mere preserve of extremist right-wing Italian political parties. Soon after his 2008 election victory, Prime Minister Silvio Berlusconi condemned undocumented immigrants in Italy as an 'army of evil,' and vowed he would 'step up neighbourhood police, who can be an army of good, placing themselves between the Italian people and the army of evil’ ('Berlusconi’ 2008: 9). Reproducing President Bush’s language of the 
'axis of evil' and the 'war on terror,' Berlusconi here strategically reframes undocumented immigrants as terrorists who have declared war on the Italian people, thereby at once criminalising and militarising this disenfranchised group of people who continue to perform dangerous and unsanitary of jobs, even as they contribute to the prosperity of the Italian economy.

Beginning with the raciological and racist theories of the Meridionalisti in the nineteenth century, a preoccupation with whiteness has inflected Italian national identity at multiple levels,. It has shaped both internal and foreign policy, including the imperial project of colonial annexation of North African states and the racialised construction of diasporic subjectivities and cultural practices (Pugliese 2002a, 2002b, 2007a, 2007b, 2007c). At the everyday level of life on Italy's streets, in cities such as Seveso and Treviso, Northern League mayors have organised vigilante squads, or ronde, to police and patrol African and Albanian itinerant workers and prostitutes. Intertwining the exercise of law and order with racist arguments enables these workers to be defined as recidivist criminals - even though, as Thomas Gold points out, those laws and arguments do 'little to condemn the (Italian) men who frequent them' as clients looking for sex and/or drugs (2003: 85).

The point of the contemporary reconnections between the South and its Souths that I broached above is eloquently articulated by a Moroccan immigrant, Majuba Agig, facing racism in the city of Milan: 'We do not take more,' she says, 'than those who arrived twenty years ago, the meridionali/Southerners. We are the brothers [and sisters] of the meridionali' (quoted in Parati 1997: 182). This point of reconnection is at stake through the increasingly draconian anti-immigrant laws being passed by the Italian government. The Souths of the South/the South of the North - this is the other of Europe: coloured, illegal, politically and economically disenfranchised. And yet these Souths are constitutive of the economic and cultural power, and white identity, of the North. The very naming of northern Italy's so-called 'opulent periphery,' comprising Veneto, Lombardy and Pidemont, as the 'white provinces' or 'white zones' (terms that refer to the dominance of the Christian Democratic party in those provinces) is not a racially neutral nomenclature when situated in the dense racialogical history of the North. It confirms a long-standing Northern anxiety to secure its whiteness/ Europeanness by casting the South as its African-Oriental other. The rise of the 
Northern League in these 'white zones' was fuelled, amongst other things, by the perceived 'threat to the well-being of these areas' posed by 'immigration, both from the South and from the Third World, which, it was maintained,' was 'facilitating a rapid rise in criminality, was undermining the high level of social and cultural integration they had achieved and so the good order of society' (Allum and Diamante 1996: 153). Umberto Bossi, the Lega's leader, exemplifies the complex intertwining of biological and cultural racisms in his argument that it is 'impossible to assimilate' these immigrants because 'the cultural differences are too great. The difference in skin colour is detrimental to social peace. Imagine if your street, your public square, was full of people of colour, you would feel no longer part of your own world' (quoted in Allum and Diamante 1996: 153). The statement underscores the racist fiction that the chromatics of racial epidermis overdetermine behavioural and cultural practices: the two are melded here.

Anna Cento Bull confirms the intertwining of biological and cultural racisms by citing from a survey 'among nearly 3,000 factory workers and union representatives employed in thirteen plants across the Lombard provinces,' which 'revealed widespread prejudices ... against both Southern Italian and coloured immigrants,' including the fear that 'Southern immigrants pollute the local culture' (1996: 179). The construction of racial difference in terms of a 'pollutant' and ‘contagion' cuts across multiple axes. Racial difference at once contaminates the 'purity' of the local culture whilst causing, in unreconstructed eugenicist terms, the 'degeneration' of the white race. In the face of this threat, an election slogan used in the 1990s by the League, 'Forza Etna, fai il tuo dovere! (Come on Etna, do your duty!)’ (Allum and Diamanti 1996: 154), clearly enunciated a racist call for 'ethnic cleansing.' However, the increasing presence of nonEuropean immigrants in Italy has also generated a shift in tactics on the part of the League. The League's explicit campaign against the South has, in recent times, largely subsided. In the 2008 elections, for example, that campaign was replaced by the dubious and opportunisitic moves to establish lines of solidarity with the Sicilian centre-right separatist party Movimento per l'autonomia (Movement for [Sicilian] Autonomy). The League continues, nonetheless, to deploy xenophobic anti-immigrant slogansincluding, in another 2008 election poster, the image of Bosi brandishing a clenched fist and declaring that his constituency needs to 'Difendi il tuo futuro: fuori i clandestini' (Defend your future: out with undocumented immigrants). At the local level, these anti- 
immigrant slogans assume more sinister dimensions when articulated by such Lega mayors as Giancarlo Gentilini, mayor of Treviso, 'who has stated that the country should ship illegal immigrants out of the country in "lead wagons", and who advocated the 'use of immigrants as targets for gun practice' (Gold 2003: 126).

In the face of the biologico-cultural racism that I have been tracking in this essay, the transformation of Italy's urban squares and streets into 'copies' of the suk of Marrakech typifies the material and cultural returns of the Souths of the South. Gallino's revulsion at the cultural transmutation of Italy's streets and squares into suks can only achieve its xenophobic moralising force by effectively liquidating, for example, southern AfricanArab histories. Only through the process of white historicide can the suk appear as an alien cultural practice within the civic spaces of the Italian state, and people of colour be framed as interlopers in Italy’s public spaces. In the South, in both Sicily and Calabria, cities such as Tropea, Saracena and, most famously, Palermo, were renowned for their suks (Jevolella 2005: 78). Given that history, migrant flows from the Global South enable lines of historical, cultural and economic re-connection between the South, Africa and the Middle East. For Southerners, there is nothing either disturbing or new in naming their cities in terms of African or Middle Eastern equivalents. Naples, for instance, has long been known as the Cairo of the South (Astarita 2005: 167), even though Lord Rosebury famously lamented that 'Naples is the only Oriental city without a European quarter' (quoted in Allum and Diamanti 1996: 165). Many southern cities and towns celebrate their foundation by invoking the union of the native southern Mata and the black Grifone-Hassam Ibn-Hammar; indeed, myth and legend provide multiple points of African and Middle Eastern origin (North African, Berber, Arab and Turk). Rather than causing, as the sociologist Gallino laments, a 'degradation' of ‘social fabric and urban spaces,' the transformation of Italy's squares and streets into African and Middle Eastern urban sites marks the cultural rearticulation of a civic sense that remains unintelligible within the eurocentric and caucacentric frames of northern citizens, politicians and cultural theorists.

The cultural transcriptions in Italian cities of African American-inspired graffiti, rap and North African suks must be seen as material manifestations of black-coded cultural tactics that reorient and resignify the sociocultural spaces and practices of an Italian nation presumed to have a white identity. Transcribed onto Italy's white-nationalist 
monuments and civic spaces, these provisional cultural practices are condemned by white-supremacist social commentators and politicians as exemplifying the degenerative 'blackening of Europe' (Raphael-Hernandez 2004). This is further evidenced by Prime Minister Berlusconi calling for more draconian anti-graffiti laws in order to curb graffiti practice, arguing that 'graffiti is making our cities more like African instead of European cities' ('Il governo' 2008: 10). Racially coded cultural practices such as 'graffiti' and suks stand to exemplify, as Gallino and others lament, forms of degrado urbano (urban decay). I would argue, in fact, that these racially-coded black cultural practices effectively solicit and interrogate the Italian nation's ongoing colonial amnesia and its violent disavowal of the constitutive role that transmediterranean North African and black transatlantic cultures have played in shaping the heterogeneous cultures of the peninsula and its islands. Even as Italy views itself as a postcolonial nation that has relegated its colonial ambitions to the past, these cultural metonyms of blackness—suks, rap and graffiti-challenge this myth through the racist anxieties and outbursts that they provoke. They thereby disclose the structural manner in which colonial relations of biopolitical power effectively organise Italian social space, caucacentrically govern and delimit 'legitimate' cultural practices, and hierarchically mark and segregate targeted racialised bodies. As Paul Gilroy argues, ‘The racisms of Europe’s colonial and imperial phase preceded the appearance of migrants inside the European citadel. It was racism, not diversity, that made their arrival into a problem’ (2004: xxi). As such, what remains to be examined is how these colonial and imperial racisms operate as structural a priori, regardless of the historical transmutations and reconfigurations of so-called postcolonial European nation-states such as Italy and their racially-inflected biopolitical regimes.

Indeed, what also remains to be examined is the extraordinary and telling absence of a corpus of whiteness studies in Italian studies, despite the fact that whiteness studies traces its genealogical roots back to the landmark work of Frantz Fanon’s Black Skin White Masks (1952). This omission is extraordinary because, as I have attempted to argue over the last decade, whiteness has been absolutely constitutive in the formation of hegemonic Italian identity, politics and culture-commencing with the historical movement of unification, through the Italian colonial campaigns and up to the contemporary racialised debates on the extracomunitari. As many whiteness scholars have argued this omission is symptomatic of the power of whiteness to be an invisible visibility. In other words, the disavowal of the centrality of whiteness in the constitution 
and reproduction of Italianness, in all its forms, dramatises how whiteness

fundamentally informs and shapes key Italian apparatuses of power and racialised subjectivities, even as it renders invisible its structural and constitutive role, effacing itself as a foundational racial category of critical inquiry.

The reclamation of squares, monuments and streets through such ephemeral forms such as graffiti, rap, suks and transient markets exemplifies the agency enabling cultural modalities of the Global South in the face of violent political and economic asymmetries of racialised power. This reclamation, an example of a 'feral beauty' (Gilroy 2004: xiv), resignifies hegemonic understandings of white/civic culture. The reclamation also articulates a street justice that reorients the historical, racial, cultural, economic and legislative exclusions of provisional lives within the corpus of the contemporary Italian nation.

\section{Reference List}

Alighieri, D. 1887, 'De vulgari eloquio/Sul vulgare eloquio,' in Dante Alighieri: I trattati, (eds) D. P. Fraticelli and G. Barbèra, Editore, Firenze, 118-253.

Allum, P. and I. Diamanti, 1996 'The Autonomous Leagues in the Veneto,' in Italian Regionalism, (ed.) C. Levy, Berg, Oxford, 151-70.

Agnoli, F. M. 2005, 'Prefazione,' in F. Izzio, I lager dei Savoia: storia infame del Risorgimento nei campi di concentramento per meridionali, Controcorrente, Napoli, 7-23.

Andall, J. and D. Duncan (eds) 2005, Italian Colonialism: Legacy and Memory, Peter Lang, New York.

Astarita, T. 2005, Between Salt Water and Holy Water: A History of Southern Italy, W. W. Norton and Company, New York and London.

Bakhtin, M. M. 1987, The Dialogic Imagination, M. Holquist (Trans.), University of Texas Press, Austin. Banfield, E. C. 1958, The Moral Basis of a Backward Society, Chicago, Free Press.

Battaglia, L. 2006, Siciliana, Electa, Milano.

Ben-Ghiat, R. and M. Fuller (eds) 2005, Italian Colonialism, Palgrave Macmillan, New York.

'Berlusconi to Deal with Italy’s Far Right' 2004, Sydney Morning Herald, 17 April, 9. Online. Available: http://www.smh.com.au/news/world/berlusconi-to-deal-with-italys-farright/2008/04/16/1208025280923.html [Accessed 1 July 2008].

Bull, A. C. 1996, 'Ethnicity, Racism and the Northern League,' in Italian Regionalism, (ed.) C. Levy, Berg, Oxford, 171-88.

Dawson, A. and P. Palumbo. 2005, 'Hannibal's Children: Immigration and Antiracist Youth Subcultures in Contemporary Italy,' Cultural Critique, no. 59, 165-86.

De Certeau, M. 1988, The Practices of Everyday Life. S. Rendall (Trans.), University of California Press, Berkeley.

De Jaco, A. 2005, Il brigantaggio meridionale, Editori Riuniti, Roma.

Del Boca, A. 2002, L’Africa nella coscienza degli italiani. Oscar Mondadori, Milano.

Del Boca, A. 2005, Italiani, brava gente?, Neri Pozza, Vicenza.

Del Boca, A. 2007, I gas di Mussolini, Editori Riuniti, Roma.

Dickie, J. 1999, Darkest Italy, St Martin’s Press, New York.

Di Fiore, Gigi. 2008, Controstoria dell'Unità d'Italia, Rizzoli, Bergamo.

Einaudi, L. 2007, Le politiche dell'immigrazione in Italia dall' Unità a oggi, Laterza, Bari.

Fanon, F. 1952/1970, Black Skin White Masks, Paladin, London.

Ferrell, J. 1996, Crimes of Style, Northwestern University Press, Boston. 
Ferrell, J. 2001, Tearing Down the Streets: Adventures in Urban Anarchy, St Martin's Press, New York. Galasso, G. 2005, Il Mezzogiorno: da 'questione' a 'problema aperto,' Lacaita, Manduria.

Gilroy, P. 1993, The Black Atlantic, Verso, London and New York.

Gilroy, P. 2004, 'Foreword: Migrancy, Culture, and a New Map of Europe,' in Blackening Europe: The African-American Presence, (ed.) H. Raphael-Hernandez, Routledge, New York, xi-xxii.

Gold, T. W. 2003, The Lega Nord and Contemporary Politics in Italy, Palgrave Macmillan, Hampshire. 'Il governo contro i graffiti,' Nuovo Paese, vol. 35, no. 9, 10.

Gramsci, A. 1975, Quaderni del carcere, vol. 3, Giulio Einaudi, Torino.

Gramsci, A. 2005, La Questione Meridionale, Editori Riuniti, Roma.

Guglielmo, J. and S. Salerno (eds) 2003, Are Italians White?, Routledge, New York.

Hebdige, D. 1987, Subculture: The Meaning of Style, Routledge, London.

Izzio, F. 1999, I lager dei Savoia: storia infame del Risorgimento nei campi di concentramento per meridionali, Controcorrente, Napoli.

Jevollela, M. 2005, Le radici islamiche dell'Europa, Boroli Editore, Milano.

Kitwana, B. 2002, The Hip Hop Generation: Young Blacks and the Crisis in African American Culture, Basic Civitas, New York.

La Repubblica.it. 2008, ““Gabbie, degrado, servizi pessimi,” La Commissione UE boccia i Cpt,’ 2 April 2008. Online: Available: http://www.republica.it/2008/04/sezioni/cronaca/rapporto-cpt/rapportocpt.html [Accessed 1 July 2008].

Lepschy, A. L., G. Lepschy and M. Voghera 1996, 'Linguistic Variety in Italy,' in Italian Regionalism, (ed.) C. Levy, Berg, Oxford, 69-80.

Martucci, R. 2007, L'invenzione dell' Italia unita, Milano, Sansoni.

Marzocco, G. 2006, 'Introduzione,' in L. Salera, Garibaldi, Fauché e i predatori del Regno del Sud, Controcorrente, Napoli, 7-25.

Medici Senza Frontiere 2007, Un stagione all'inferno. Online. Available: http://www.medicisenzafrontiere.it/msfinforma/pubblicazioni.asp?id=1644 [Accessed 1 July 2008].

Mezzadra, S. 2007, 'Il nuovo regime migratorio europeo e le metamorfosi contemporanee del razzismo,' Studi sulla questione criminale, no. 1, 13-29.

Mehta Uday S. 1999, Liberalism and Empire, University of Chicago Press, Chicago.

Mitchell, T. 1996, Popular Music and Local Identity, Leicester University Press, Leicester.

Mitchell, T. 2000, ‘Doin’ Damage in My Native Language: The Use of “Resistance Vernaculars” in Hip Hop in France, Italy, and Aotearoa/New Zealand,' Popular Music and Society, vol. 24, no.3, 41-54.

Moe, N. 2002, The View from Vesuvius, University of California Press, Berkeley.

Parati, G. 1997, 'Strangers in Paradise: Foreigners and Shadows in Italian Literature,' in Revisioning Italy, (eds) B. Allen and M. Russo, University of Minnesota Press, Minneapolis, 169-90.

Petraccone, C. 2000, Le due civiltà, Laterza, Roma and Bari.

Pugliese, J. 2002a, 'Race as Category Crisis: Whiteness and the Topical Assignation of Race,' Social Semiotics, vol. 12, no. 2, 149-68.

Pugliese, J. 2002b, 'In the Ruins of Diaspora: A Southern Italian Perspective,' in Issues in Travel Writing: Empire, Spectacle, and Displacement, (ed.) K. Siegel, Peter Lang, New York, 229-44.

Pugliese, J. 2007a, 'Diasporic Architecture, Whiteness and the Cultural Politics of Space: In the Footsteps of the Italian Forum,” in Constellations of the Transnational: Modernity, Culture, Critique, (ed.) S. Dasgupta, Rodopi, Amsterdam and New York, 23-49.

Pugliese, J. 2007b, 'White Historicide and the Returns of the Souths of the South,' Australian Humanities Review, vol. 42. Online: Available: http://www.lib.latrobe.edu/AHR/archive/Issue-August2007/Pugliese.html [Accessed 1 July 2008].

Pugliese, J. 2007c, 'Le Altre Italie: Identità Geopolitiche, Genealogie Razzializzate e Storie Interculturali,' Studi emigrazione, vol. 16, 837-54.

Pugliese, J. Forthcoming, 'Civil Modalities of Refugee Trauma, Death and Necrological Transport,' Social Identities.

Putnam, R. D. 1993, Making Modern Democracy Work: Civic Traditions in Modern Italy, Princeton, NJ, Princeton University Press.

Raphael-Hernandez, H. (ed.) 2004, Blackening Europe: The African American Presence, Routledge, New York.

Salera, L. 2006, Garibaldi, Fauché e i predatori del Regno del Sud, Controcorrente, Napoli.

Scarpino, S. 2005, La guerra 'cafona,’ Boroli Editore, Milano.

Sciorra, J. 2007, ‘Italian Rap.’ Online. Available: http://www.italianrap.com/masterfr.html. [Accessed 12 December 2007].

Schneider, J. (ed.) 1998, Italy’s 'Southern Question’: Orientalism in One Country, Berg, Oxford. 
Teti, V. 1993, La razza maladetta, Manifestolibri, Roma.

Toop, D. 2002, Rap Attack: African Rap to Global Hip Hop, Serpent's Tail, London.

Turco, L. 2006, I nuovi italiani, Oscar Mondadori, Milano.

\section{Discography}

Bennato, E. 2008, Grande sud, Taranta Power.

Bennato, E. N.d., Che il meditteraneo sia, Taranta Power.

99 Posse. 1993, Curre curre guaglió, BMG Ricordi SpA.

Nuovi Briganti. 1993, Fottuto terrone, Cyclope Records.

Nour Eddine and Phaleg. 2003. Taragnawa. Compagnia Nuove Indye.

Spaccanapoli. 2000, Aneme perze, Real World Records. 